\title{
Calcification of the main reef-building coral species on the Pacific coast of southern Mexico
}

\section{Calcificación de las principales especies de corales constructoras de arrecifes en la costa del Pacífico del sur de México}

\author{
Francisco Medellín-Maldonado ${ }^{1}$, Rafael Andrés Cabral-Tena ${ }^{1}$, Andrés López-Pérez ${ }^{1 *}$, \\ Luis E Calderón-Aguilera², C Orión Norzagaray-López ${ }^{3}$, Cecilia Chapa-Balcorta ${ }^{4}$, \\ Ronald C Zepeta-Vilchis ${ }^{4}$
}

${ }^{1}$ Laboratorio de Ecosistemas Costeros, Departamento de Hidrobiología, Universidad Autónoma Metropolitana (UAM), San Rafael Atlixco 186, Col. Vicentina, Delegación Iztapalapa, 09340 Ciudad de México, México.

2 Centro de Investigación Científica y de Educación Superior de Ensenada (CICESE), Carretera Ensenada-Tijuana no. 3918, Zona Playitas, 22860 Ensenada, Baja California, México.

${ }^{3}$ Instituto de Investigaciones Oceanológicas, Universidad Autónoma de Baja California, Carretera Transpeninsular Ensenada-Tijuana no. 3917, Fraccionamiento Playitas, 22860 Ensenada, Baja California, México.

${ }^{4}$ Universidad del Mar, Ciudad Universitaria, 70902 Distrito de San Pedro Pochutla, Puerto Ángel, Oaxaca, México.

* Corresponding author. E-mail: alopez@xanum.uam.mx

\begin{abstract}
Global warming and ocean acidification affect coral calcification. Nevertheless, there is not enough information regarding the growth parameters of the main reef-building coral species in marginal growth areas such as the Pacific coast of southern Mexico. In order to fill this gap, coral growth parameters of 8 hermatypic coral species (massive species: Porites panamensis, Porites lobata, Pavona gigantea, and Pavona varians; branching species: Pocillopora meandrina, Pocillopora damicornis, Pocillopora verrucosa, and Pocillopora capitata) were estimated in 2 areas of the southern Mexican Pacific. Branching coral species had a higher calcification rate $\left(2.99-5.23 \mathrm{~g} \mathrm{CaCO}_{3} \mathrm{~cm}^{-2} \mathrm{yr}^{-1}\right)$ than massive species $\left(0.34-1.13 \mathrm{~g} \mathrm{CaCO}_{3} \mathrm{~cm}^{-2} \mathrm{yr}^{-1}\right)$. A significant relation between sea surface temperature (SST) and skeletal density was observed in all massive coral species. Also, 2 massive species ( $P$. gigantea and $P$. varians) showed a significant relation between SST and calcification rate. Upwelling in the Gulf of Tehuantepec transports deep water with low $\mathrm{pH}$ and low aragonite saturation, and may be affecting the calcification rate of stony corals in the studied area.
\end{abstract}

Key words: coral growth, density, Pocillopora, Pavona, Porites.

RESUMEN. El calentamiento global y la acidificación del océano influyen en la calcificación de los corales. No obstante, existe poca información respecto a los parámetros de crecimiento de las principales especies de corales constructores de arrecifes en áreas de crecimiento marginales como la costa del Pacífico del sur de México. Se obtuvieron los parámetros de crecimiento de 8 especies de corales hermatípicos (especies con crecimiento masivo: Porites panamensis, Porites lobata, Pavona gigantea y Pavona varians; especies con crecimiento ramificado: Pocillopora meandrina, Pocillopora damicornis, Pocillopora verrucosa y Pocillopora capitata) en 2 zonas de la costa del Pacífico del sur de México. Los corales ramificados tuvieron tasas de calcificación más altas (2.99-5.23 $\mathrm{g} \mathrm{CaCO}_{3} \mathrm{~cm}^{-2}$ año-1) que los corales masivos (0.34-1.13 $\mathrm{g} \mathrm{CaCO}_{3} \mathrm{~cm}^{-2}$ año ${ }^{-1}$ ). Se observó una relación significativa entre la temperatura superficial del mar (TSM) y la densidad del esqueleto para todas las especies de coral masivo. Además, 2 especies de coral masivo ( $P$. gigantea y $P$. varians) mostraron una relación significativa entre la tasa de calcificación y la TSM. Las surgencias en la región del golfo de Tehuantepec acarrean aguas con bajo pH y baja saturación de aragonita, y podrían estar afectando negativamente la tasa de calcificación de los corales en el área de estudio.

Palabras clave: crecimiento coralino, densidad, Pocillopora, Pavona, Porites.

\section{INTRODUCTION}

Studies aiming to understand the calcification process in hermatypic corals and the factors that limit their growth have been conducted since the 1960s. Wells (1963) determined that coral growth parameters are directly related to seasonal variations in environmental conditions. Knutson et al. (1972) subsequently confirmed this theory and recognized annual

\section{INTRODUCCIÓN}

Desde la década de 1960 , se han realizado estudios para comprender el proceso de calcificación que llevan a cabo los corales hermatípicos y conocer los factores que limitan su crecimiento. Wells (1963) determinó que los parámetros de crecimiento coralino guardan una relación directa con las variaciones estacionales en las condiciones ambientales. 
pairs of high- and low-density skeletal growth bands that represent the seasons when the calcification rates are higher and lower. This coral banding pattern provides a means of analyzing, retrospectively, the growth parameters of coralline skeleton based on three variables containing complementary information: (1) skeletal extension rate, (2) skeletal density (which depends directly on the density of aragonite [2.94 $\mathrm{g} \mathrm{cm}^{-3}$ ], the pores in the skeleton being responsible for affecting this value [Hughes 1987]), and (3) calcification rate (Dodge and Brass 1984, Carricart-Ganivet et al. 2000). Moreover, skeletal bands are associated with the prevailing environmental conditions where corals develop, and are thus an important tool for reconstructing the environmental conditions at coral reef locations (Knutson et al. 1972, Buddemeier 1974, Chalker et al. 1985).

The environmental variables that exert the greatest effect on coral growth are light (Buddemeier 1974, Wellington and Glynn 1983, Falkowski 2000, Yentsch et al. 2002), sedimentation (Dodge et al. 1974, Loya 1976, Barnes and Lough 1999, Fabricius 2005), nutrient concentrations (Atkinson and Bilger 1992, Lough et al. 1999, Fabricius 2005), aragonite saturation state $\left(\Omega_{\text {aragonite }}\right)$ (Gattuso et al. 1998, Kleypas et al. 1999, Langdon et al. 2000, Marubini et al. 2001), pH (Atkinson et al. 1994, Marubini and Atkinson 1999, Kleypas and Langdon 2006), and sea surface temperature (SST) (Dodge et al. 1974, Veron 1995, Lough and Barnes 2000, Cruz-Piñón et al. 2003, Carricart-Ganivet 2004, CarricartGanivet et al. 2012, Cabral-Tena et al. 2013, NorzagarayLópez et al. 2013).

Coral growth and its variation are considered to be controlled by 2 factors: (1) the amount of energy available for the deposition of the calcareous material (known as calcification rate) and (2) the way the coral uses this material to construct its skeleton. Differences in the latter result in 2 growth strategies: investing calcification resources into skeletal density or into skeletal extension (Carricart-Ganivet 2007).

In the eastern Pacific and Mexican Caribbean, massive corals belonging to the genera Porites and Orbicella exhibit an annual growth pattern: in late summer, when SST is higher, they deposit a denser skeleton and a high-density band is formed; conversely, when SST decreases, the skeletal density diminishes and a low-density band is formed (Highsmith 1979, Barnes and Lough 1993, Lough and Barnes 2000, Carricart-Ganivet 2004). Hence, a pair of growth bands of different density (high, low) represents one year of growth (Barnes and Lough 1993). The annual calcification rate $\left(\mathrm{g} \mathrm{CaCO}_{3} \mathrm{~cm}^{-2} \mathrm{yr}^{-1}\right.$ ), which according to Dodge and Brass (1984) is the product of skeletal density $\left(\mathrm{g} \mathrm{CaCO}_{3} \mathrm{~cm}^{-3}\right)$ and extension rate $\left(\mathrm{cm} \mathrm{yr}^{-1}\right)$, can thus be determined by analyzing the pattern of alternating bands in coral skeletons.

Given the relationship between coral growth and environmental conditions (Knutson et al. 1972), it is essential to determine the basic parameters of calcification (i.e., density, extension) and the environmental factors that regulate them at regional scale, especially in the case of coral species that
Knutson et al. (1972) confirmaron esta teoría y reconocieron pares de bandas de crecimiento anual, de alta y baja densidad, en el esqueleto de los corales, las cuales representan las épocas de mayor y menor calcificación. Este patrón de bandas permite analizar, retrospectivamente, los parámetros de crecimiento del esqueleto coralino mediante 3 variables que contienen información complementaria: (1) la tasa de extensión del esqueleto, (2) la densidad del esqueleto (la cual depende directamente de la densidad de la aragonita [2.94 $\left.\mathrm{g} \mathrm{cm}^{-3}\right]$, y los poros en el esqueleto son los responsables de afectar este valor [Hughes 1987]) y (3) la tasa de calcificación (Dodge y Brass 1984, Carricart-Ganivet et al. 2000). Además, las bandas en el esqueleto coralino están asociadas a las condiciones ambientales predominantes donde se desarrolla el coral y, por tanto, son una herramienta importante para reconstruir las condiciones ambientales en donde habitan los corales (Knutson et al. 1972, Buddemeier 1974, Chalker et al. 1985).

Las variables ambientales que más influyen en el crecimiento coralino son la luz (Buddemeier 1974, Wellington y Glynn 1983, Falkowski 2000, Yentsch et al. 2002), la sedimentación (Dodge et al. 1974, Loya 1976, Barnes y Lough 1999, Fabricius 2005), la concentración de nutrientes (Atkinson y Bilger 1992, Lough et al. 1999, Fabricius 2005), el estado de saturación de la aragonita $\left(\Omega_{\text {aragonita) }}\right.$ (Gattuso et al. 1998, Kleypas et al. 1999, Langdon et al. 2000, Marubini et al. 2001), el pH (Atkinson et al. 1994, Marubini y Atkinson 1999, Kleypas y Langdon 2006) y la temperatura superficial del mar (TSM) (Dodge et al. 1974, Veron 1995, Lough y Barnes 2000, Cruz-Piñón et al. 2003, Carricart-Ganivet 2004, Carricart-Ganivet et al. 2012, Cabral-Tena et al. 2013, Norzagaray-López et al. 2013).

El crecimiento de los corales y su variación están controlados por 2 factores: (1) la cantidad de energía disponible para la precipitación de material calcáreo (conocido como tasa de calcificación) y (2) la manera en la que este material es utilizado por el coral para construir su esqueleto. Las diferencias en este último resultan en 2 estrategias de crecimiento de los corales: invertir los recursos para calcificar y formar esqueletos más densos, o bien, para formar esqueletos con mayor extensión (Carricart-Ganivet 2007).

En el Pacífico oriental y el Caribe mexicano, se ha observado que los corales masivos pertenecientes a los géneros Porites y Orbicella siguen un patrón anual de crecimiento: a finales del verano, cuando la TSM es alta, depositan un esqueleto más denso y se forma una banda de alta densidad; contrariamente, cuando la TSM disminuye, reduce también la densidad de su esqueleto y se forma una banda de baja densidad (Highsmith 1979, Barnes y Lough 1993, Lough y Barnes 2000, Carricart-Ganivet 2004). Así, un par de bandas de crecimiento de distinta densidad (alta, baja) representa un año de crecimiento (Barnes y Lough 1993). Con esto en consideración, el análisis del patrón de bandas alterno en el esqueleto de los corales permite conocer la tasa de calcificación anual $\left(\mathrm{g} \mathrm{CaCO}_{3} \mathrm{~cm}^{-2}\right.$ año $\left.{ }^{-1}\right)$, que de acuerdo con Dodge y Brass 
most strongly contribute to the structural development of the reef system. The growth of scleractinian corals is responsible for the persistence of coral reefs over time (Manzello 2010). Thus, the state of these species and the health status of the reef in general can be assessed by quantifying the calcification rate of the main reef-forming species and identifying the environmental variables that regulate this process. Moreover, the information provided by the skeletal density bands allows environmental reconstructions of the periods when the coral developed, which can be used to infer the response of coral reefs to future climate scenarios (Buddemeier et al. 2004, IPCC 2007). This is particularly relevant in the case of those species or regions where reefs develop under marginal environmental conditions. Since the end of the 19th century, the Eastern Tropical Pacific is considered to be a suboptimal area for reef development because it has a narrow continental shelf, high productivity, relatively cold waters, and seasonal upwelling (Glynn and Ault 2000), as well as water with a low pH and low $\Omega_{\text {aragonite }}$ (Manzello et al. 2008, Manzello 2010). These last 2 elements turn the eastern Pacific into a natural laboratory for studying the effects of an ocean with high levels of $\mathrm{CO}_{2}$ on the processes regulating calcification in coral species and reef development. Despite its relevance, only a few studies have been conducted on coral calcification in the eastern Pacific (Glynn and Wellington 1983; Wellington and Glynn 1983; Halfar et al. 2005; Calderón-Aguilera et al. 2007; Reyes-Bonilla and López-Pérez 2009; Cabral-Tena et al. 2013; Norzagaray-López et al. 2013, 2014), and of these studies, even fewer have reported growth values obtained in situ (Glynn and Wellington 1983; Wellington and Glynn 1983; Cabral-Tena et al. 2013; Norzagaray-López et al. 2013, 2014). To date, in situ estimates have been reported for the Galapagos Islands (Glynn and Wellington 1983, Wellington and Glynn 1983) and the Gulf of California (Cabral-Tena et al. 2013; Norzagaray-López et al. 2013, 2014; Tortolero-Langarica 2016). There are no estimates for corals that develop in Pacific waters off southern Mexico.

The reefs on the Pacific coast of tropical southern Mexico are relatively small and discontinuous, and have a low diversity of coral species (Reyes-Bonilla 2003). There is a predominance of Pocillopora spp. and to a lesser extent of Pavona spp. and Porites spp. (Glynn and Leyte-Morales 1997, López-Pérez et al. 2012). The Pacific reefs of Mexico are divided into 5 regions. Of these, the southern Pacific region comprises the reef formations found off IxtapaZihuatanejo in the state of Guerrero (López-Pérez et al. 2012) and off Puerto Ángel (Reyes-Bonilla and Leyte-Morales 1998) and Bahías de Huatulco in the state of Oaxaca (Glynn and Leyte-Morales 1997, López-Pérez and HernándezBallesteros 2004). These 2 areas have different climate and oceanographic conditions. Specifically, the Huatulco area is influenced by seasonal upwelling that occurs in the Gulf of Tehuantepec, which elevates subsurface water with low $\mathrm{pH}$, low $\Omega_{\text {aragonite }}$ and variations in SST to the surface (ChapaBalcorta et al. 2015). In contrast, the Ixtapa-Zihuatanejo area
(1984) es el producto de la tasa de extensión del esqueleto ( $\mathrm{cm}$ año ${ }^{-1}$ ) y la densidad del mismo $\left(\mathrm{g} \mathrm{CaCO}_{3} \mathrm{~cm}^{-3}\right)$.

Considerando que el crecimiento coralino está relacionado con las condiciones ambientales en donde se desarrollan los corales (Knutson et al. 1972), la determinación de los parámetros básicos de calcificación (i.e., extensión, densidad) y los factores ambientales que los regulan a escala regional, especialmente para aquellas especies de coral que contribuyen en mayor medida al desarrollo estructural del sistema arrecifal, se vuelve indispensable. El crecimiento de los corales escleractinios es responsable de la persistencia de los arrecifes coralinos a través del tiempo (Manzello 2010). Así, cuantificar la tasa de calcificación de las principales especies de corales formadores de arrecife y conocer las variables ambientales que regulan este proceso permite evaluar el estado en el que se encuentran estas especies y el estado de salud del arrecife en general. Adicionalmente, la información contenida en las bandas de densidad de los esqueletos permite hacer reconstrucciones ambientales de los periodos en los que se desarrolló el coral y, con esto, inferir la respuesta del crecimiento coralino ante escenarios climáticos futuros (i.e., Buddemeier et al. 2004, IPCC 2007). Lo anterior se vuelve particularmente relevante para aquellas especies o regiones donde los arrecifes se desarrollan en condiciones ambientalmente marginales. Desde finales del siglo XIX, se ha reconocido que el Pacífico oriental tropical representa una zona subóptima para el desarrollo arrecifal porque presenta una plataforma continental estrecha, alta productividad, aguas relativamente frías y surgencias estacionales (Glynn y Ault 2000), además de agua con bajo $\mathrm{pH}$ y baja $\Omega_{\text {aragonita }}$ (Manzello et al. 2008, Manzello 2010). De manera particular, estos 2 últimos elementos convierten al Pacífico oriental en un laboratorio natural para estudiar los efectos de un océano con altos niveles de $\mathrm{CO}_{2}$ en los procesos que regulan la calcificación de las especies de coral y el desarrollo arrecifal. A pesar de la relevancia del tema, existe un número limitado de estudios respecto a la calcificación de corales en el Pacífico oriental (Glynn y Wellington 1983; Wellington y Glynn 1983; Halfar et al. 2005; Calderón et al. 2007; Reyes-Bonilla y López-Pérez 2009; Cabral-Tena et al. 2013; NorzagarayLópez et al. 2013, 2014), de los cuales un número aún más escaso ha reportado valores de crecimiento obtenidos in situ (Glynn y Wellington 1983; Wellington y Glynn 1983; CabralTena et al. 2013; Norzagaray-López et al. 2013, 2014). A la fecha, las estimaciones in situ han sido llevadas a cabo en las islas Galápagos (Glynn y Wellington 1983, Wellington y Glynn 1983) y el golfo de California (Cabral-Tena et al. 2013; Norzagaray-López et al. 2013, 2014; TortoleroLangarica 2016), pero se carece de estimaciones para corales que se desarrollan en la costa del Pacífico del sur de México.

Las aguas tropicales mexicanas del Pacífico se caracterizan por presentar arrecifes relativamente pequeños, discontinuos y con baja diversidad de especies de coral (Reyes-Bonilla 2003). Generalmente, hay un dominio de Pocillopora spp. y contribuciones menos importantes de 
has more stable SST conditions (Morales et al. 2008) and higher $\Omega_{\text {aragonite }}$ (Reyes-Bonilla et al. 2014). These differences could be reflected in the growth parameters of reef-forming corals from each area, but they have not been determined for either of these 2 areas or for any of the species. Understanding the growth parameters and the growth-regulating factors is necessary considering that a recent evaluation of the carbon system in the region (Chapa-Balcorta et al. 2015) revealed that reefs may experience stress because of more extreme ocean acidification conditions than previously suggested (Manzello et al. 2008, Manzello 2010).

The present study aimed to determine the extension rate, density, and calcification rate of the main reef-building species (Pocillopora meandrina, Pocillopora damicornis, Pocillopora verrucosa, Pocillopora capitata, Porites panamensis, Porites lobata, Pavona gigantea, and Pavona varians) in Pacific waters off southern Mexico, to assess the effect of SST on the growth of these species, and to compare the calcification parameters obtained with those obtained by other authors at other latitudes. This is relevant at a time when possible climate change (global warming) scenarios and their influence on coastal and reef systems are being discussed.

\section{MATERIALS AND METHODS}

\section{Study area}

Coral colonies were collected at 2 sites on the Pacific coast of southern Mexico with different oceanographic conditions (Fig. 1). La Entrega (Oaxaca; $15^{\circ} 44^{\prime} 34^{\prime \prime} \mathrm{N}$, $96^{\circ} 07^{\prime} 35^{\prime \prime} \mathrm{W}$ ), located on the west side of the Gulf of Tehuantepec, is affected by strong intermittent northerly winds that generate strong upwelling (Chapa-Balcorta et al. 2015). During the upwelling periods (October to April), SST can drop as much as $8{ }^{\circ} \mathrm{C}$ (annual mean $28.7^{\circ} \mathrm{C}$ ), and lower $\mathrm{pH}$ and $\Omega_{\text {aragonite }}$ are recorded (Chapa-Balcorta et al. 2015 ). At the second site, Zacatoso (Guerrero; $17^{\circ} 39^{\prime} 14^{\prime \prime} \mathrm{N}$, $101^{\circ} 37^{\prime} 19^{\prime \prime} \mathrm{W}$ ), the environmental parameters are typical of the Pacific coast of southern Mexico: mean annual SST of $29.2^{\circ} \mathrm{C}$ (Morales et al. 2008), with annual thermal variations of less than $2{ }^{\circ} \mathrm{C}$; mean surface salinity of 34 ; a stable, shallow (20-40 m) thermocline (Fiedler and Talley 2006); and higher $\Omega_{\text {aragonite }}$ (Reyes-Bonilla et al. 2014). Unlike La Entrega, Zacatoso is not affected by upwelling events that affect SST, pH, and $\Omega_{\text {aragonite }}$.

\section{Field work}

During September and November 2010, at La Entrega and Zacatoso, 40 fragments of hermatypic corals, previously obtained from healthy colonies, were placed within a PVC structure anchored at $5 \mathrm{~m}$ depth and fixed with epoxy resin. The colonies were stained with alizarin red as a reference
Pavona spp. y Porites spp. (Glynn y Leyte-Morales 1997, López-Pérez et al. 2012). De las 5 regiones en que se dividen los arrecifes del Pacífico en México, la región del sur está conformada por las formaciones arrecifales frente a IxtapaZihuatanejo en el estado de Guerrero (López-Pérez et al. 2012) y frente a Puerto Ángel (Reyes-Bonilla y LeyteMorales 1998) y Bahías de Huatulco en el estado de Oaxaca (Glynn y Leyte-Morales 1997, López-Pérez y HernándezBallesteros 2004). Estas 2 zonas presentan condiciones climáticas y oceanográficas diferentes. En específico, la zona de Huatulco está influenciada por surgencias estacionales que ocurren en el golfo de Tehuantepec, las cuales transportan agua subsuperficial con bajo $\mathrm{pH}$, baja $\Omega_{\text {aragonita }}$ y variaciones en la TSM (Chapa-Balcorta et al. 2015). En contraste, la zona arrecifal de Ixtapa-Zihuatanejo tiene condiciones más estables en la TSM (Morales et al. 2008) y mayor $\Omega_{\text {aragonita }}$ (Reyes-Bonilla et al. 2014). Estas diferencias en las condiciones podrían verse reflejadas en los parámetros de crecimiento de los corales constructores de arrecifes de cada zona. Sin embargo, para ninguna de estas zonas se han determinado los parámetros de crecimiento de ninguna de las especies de coral. Conocer los parámetros de crecimiento coralino y los factores que lo regulan se vuelve particularmente necesario si consideramos que la reciente evaluación del sistema de carbonatos de la región (Chapa-Balcorta et al. 2015) reveló que los arrecifes podrían experimentar condiciones de estrés por acidificación más extremas que lo previamente sugerido (Manzello et al. 2008, Manzello 2010).

En este sentido, la presente investigación tuvo por objetivo determinar la tasa de extensión, la densidad y la tasa de calcificación de las principales especies constructoras de arrecifes (Pocillopora meandrina, Pocillopora damicornis, Pocillopora verrucosa, Pocillopora capitata, Porites panamensis, Porites lobata, Pavona gigantea y Pavona varians) en aguas del Pacífico frente al sur de México, evaluar el efecto que tiene la TSM en el crecimiento de estas especies y comparar los parámetros de calcificación obtenidos en este estudio con los reportados por otros autores para diferentes latitudes. Esto es relevante en un momento en el que se debaten los probables escenarios del calentamiento global (cambio climático) y su influencia en los ecosistemas costeros y arrecifales.

\section{MATERIALES Y MÉTODOS}

\section{Área de estudio}

Se recolectaron colonias de coral en 2 sitios con condiciones oceanográficas diferentes (Fig. 1). La Entrega (Oaxaca; $15^{\circ} 44^{\prime} 34^{\prime \prime} \mathrm{N}, 96^{\circ} 07^{\prime} 35^{\prime \prime} \mathrm{W}$ ) está situado en el margen occidental del golfo de Tehuantepec. En esta zona, producto de fuertes vientos provenientes del norte, se presentan intensos periodos de surgencias (octubre-abril) (Chapa-Balcorta et al. 2015). En estos periodos, se ha observado que la TSM puede 
point to later measure skeletal extension (Barnes 1972). The fixed and stained corals were extracted in October and November 2013. At the end of the period, at La Entrega we collected 4 colonies of Pocillopora meandrina, 9 of Pocillopora damicornis, 2 of Pocillopora capitata, 8 of Porites panamensis, and 4 of Pavona varians. At Zacatoso, we collected 3 colonies of Pocillopora verrucosa, 5 of Porites lobata, and 5 of Pavona gigantea. The branching corals ranged from 9 to $15 \mathrm{~cm}$ in height and from 8 to $10 \mathrm{~cm}$ in width. The massive corals ranged from 4 to $9 \mathrm{~cm}$ in height and from 8 to $12 \mathrm{~cm}$ in width.

\section{Growth parameters}

The skeletal density $\left(\mathrm{g} \mathrm{CaCO}_{3} \mathrm{~cm}^{-3}\right)$ and extension rate $\left(\mathrm{cm} \mathrm{yr}^{-1}\right)$ of each colony was determined. In the case of the Pocillopora colonies (branching corals), skeletal extension was obtained by measuring the distance from the alizarin red line to the apex of the ramification with a digital vernier ( $\pm 0.1 \mathrm{~mm}$ accuracy). Skeletal density was estimated by the displacement method (Brown and Scoffin 1986). The calcification rate $\left(\mathrm{g} \mathrm{CaCO}_{3} \mathrm{~cm}^{-2} \mathrm{yr}^{-1}\right)$ was calculated as the product of skeletal density and extension rate (Lough and Barnes 2000). descender hasta $8{ }^{\circ} \mathrm{C}$ (promedio anual $28.7^{\circ} \mathrm{C}$ ), y se ha registrado una disminución en el pH y una menor $\Omega_{\text {aragonita }}$ (ChapaBalcorta et al. 2015). Por su parte, Zacatoso (Guerrero; $\left.17^{\circ} 39^{\prime} 14^{\prime \prime} \mathrm{N}, 101^{\circ} 37^{\prime} 19^{\prime \prime} \mathrm{W}\right)$ presenta parámetros ambientales típicos de las aguas del Pacífico del sur de México: una TSM media anual de $29.2^{\circ} \mathrm{C}$ (Morales et al. 2008), oscilaciones térmicas anuales menores que $2{ }^{\circ} \mathrm{C}$, una salinidad superficial media de 34 , una termoclina estable y poco profunda (20-40 m) (Fiedler y Talley 2006) y una mayor $\Omega_{\text {aragonita }}$ (Reyes-Bonilla et al. 2014). A diferencia de La Entrega, Zacatoso no está influenciado por eventos de surgencia que afecten la TSM, el pH y la concentración de $\Omega_{\text {aragonita }}$.

\section{Actividades de campo}

Durante septiembre y noviembre de 2010, 40 fragmentos de corales hermatípicos obtenidos previamente de colonias saludables fueron fijadas con plastilina epóxica en una estructura de PVC anclada a $5 \mathrm{~m}$ de profundidad en Zacatoso y La Entrega. Para tener un registro puntal del crecimiento, las colonias fueron marcadas con rojo de alizarina (Barnes 1972). Los corales fijados y marcados fueron extraídos en octubre y noviembre de 2013. Al final del periodo, se recolectaron en La Entrega, 4 colonias de Pocillopora meandrina,
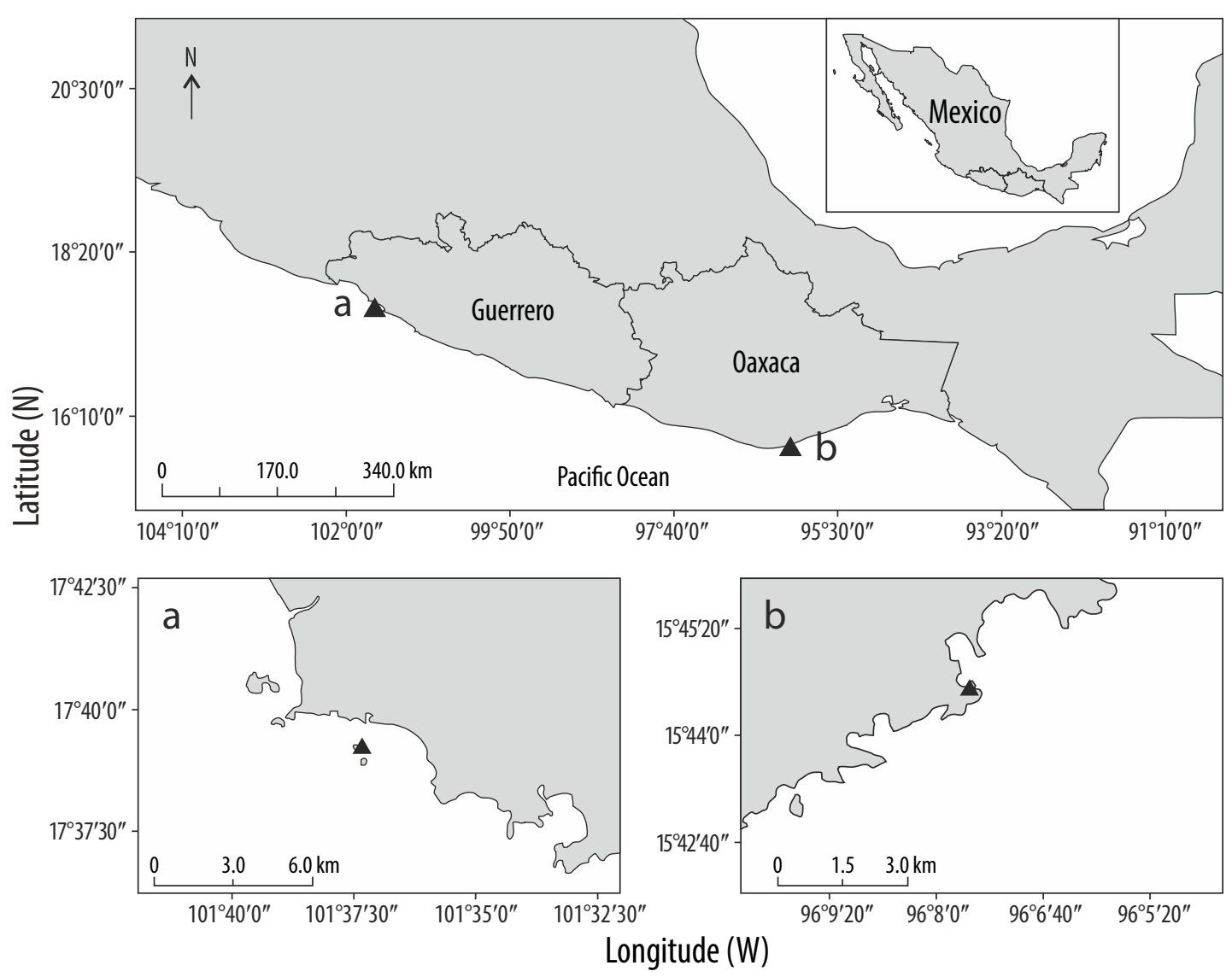

Figure 1. Geographic location of the sampling sites (triangle): (a) Zacatoso reef and (b) La Entrega reef.

Figura 1. Localización geográfica de los sitios de muestreo (triángulo): (a) arrecife Zacatoso y (b) arrecife La Entrega. 
In the case of the Porites and Pavona colonies (massive corals), each colony was cut into 7-mm-thick slices along the growth axis using a high-velocity saw. Each slice was washed and left to dry in the sun for $24 \mathrm{~h}$. The slices were X-radiographed with a digital mammography machine (Senographe $600 \mathrm{~T}$ Senix HF, Waukesha, WI) at 34-40 kVp for $60 \mathrm{~s}$, using a focal distance of $45 \mathrm{~cm}$. During each exposure an aragonite standard was used consisting of 8 blocks of known thickness and density $\left(2.83 \mathrm{~g} \mathrm{CaCO}_{3} \mathrm{~cm}^{-3}\right)$ built from a shell of Tridacna maxima (Carricart-Ganivet and Barnes 2007). The digitized $X$-ray images were used to measure the growth parameters based on optical densitometry (CarricartGanivet and Barnes 2007). The coral growth bands from each image were analyzed using Image J v.1.44 (https:// imagej.nih.gov/ij/). Annual skeletal extension rate $\left(\mathrm{cm} \mathrm{yr}^{-1}\right)$ was estimated as the linear distance between two consecutive low-density bands. Average annual density $\left(\mathrm{g} \mathrm{CaCO}_{3} \mathrm{~cm}^{-3}\right)$ was defined as the average density between adjacent density minima and maxima for each pair of bands. Finally, The annual calcification rate $\left(\mathrm{g} \mathrm{CaCO}_{3} \mathrm{~cm}^{-2} \mathrm{yr}^{-1}\right)$ was obtained from the product of average annual density and annual growth of each pair of bands (Lough and Barnes 2000).

To analyze the seasonal effect of SST on the growth parameters of massive corals (Porites and Pavona), 6-month growth rates were obtained. We performed a sclerochronological analysis using the density profile generated by optical densitometry (Carricart-Ganivet and Barnes 2007) for the annual calcification rate estimation, as well as the dates of collection (October and November 2013) and alizarin staining (September and November 2010). The bands behind the staining line were considered to be prior to 2010. Considering that a pair of different density (high, low) growth bands represents one year of growth (Barnes and Lough 1993), each band was read individually (instead of in pairs, as for the annual estimation) to obtain the 6-month growth values (Fig. 2). The 6-month skeletal extension was calculated as the linear distance occupied by each high- or low-density band. Average 6-month density was estimated as the average density between the minimum and maximum density of each individual band. The 6-month calcification rate was calculated as the product between 6-month average density and linear extension rate.

\section{Sea surface temperature}

For each site, SST values (maximum, minimum, and monthly mean \pm standard deviation) were obtained from images generated by the MODIS sensor aboard the Aqua satellite at a spatial resolution of $4 \mathrm{~km}$ (http://oceancolor.gsfc.nasa.gov/cgi/13) for the period from January 2007 to December 2013. To compare SST with the coral growth bands, these values were grouped into two 6-month periods: December to May (winter) and June to November (summer). Considering that the resolution $(4 \times 4 \mathrm{~km})$ of the MODISderived SST data may not represent the temperature at the
9 de Pocillopora damicornis, 2 de Pocillopora capitata, 8 de Porites panamensis y 4 de Pavona varians. En Zacatoso, se recolectaron 3 colonias de Pocillopora verrucosa, 5 de Porites lobata y 5 de Pavona gigantea. Las colonias de corales ramificados presentaron una altura de 9 a $15 \mathrm{~cm}, \mathrm{y}$ un espesor de $8 \mathrm{a} 10 \mathrm{~cm}$. Los corales masivos midieron de $4 \mathrm{a}$ $9 \mathrm{~cm}$ de altura y de 8 a $12 \mathrm{~cm}$ de espesor.

\section{Parámetros de crecimiento}

Se determinó la tasa de extensión ( $\mathrm{cm}$ año ${ }^{-1}$ y la densidad del esqueleto $\left(\mathrm{g} \mathrm{CaCO}_{3} \mathrm{~cm}^{-3}\right)$ de cada colonia. En el caso de las colonias de Pocillopora (crecimiento ramificado), la extensión del esqueleto se obtuvo midiendo, con un vernier digital $( \pm 0.1 \mathrm{~mm}$ de precisión), la distancia desde la línea teñida de rojo de alizarina hasta el ápice de la ramificación. La densidad del esqueleto se estimó por el método de volumen desplazado (Brown y Scoffin 1986). La tasa de calcificación $\left(\mathrm{g} \mathrm{CaCO}_{3} \mathrm{~cm}^{-2}\right.$ año-1) se calculó como el producto de la densidad y la extensión del esqueleto (Lough y Barnes 2000).

En el caso de las colonias de Porites y Pavona (crecimiento masivo), cada colonia se cortó en lajas de $7 \mathrm{~mm}$ de espesor a lo largo del eje de crecimiento con una sierra de alta velocidad. Cada laja fue lavada y puesta a secar al sol por $24 \mathrm{~h}$. Las lajas de coral fueron radiografiadas con un equipo de rayos X para mamografía digital (Senographe 600T Senix HF, Waukesha, WI) a 34-40 kVp durante $60 \mathrm{~s}$ de exposición y con $45 \mathrm{~cm}$ de distancia focal. En cada exposición se empleó un estándar de aragonita constituido por 8 bloques de grosor y densidad conocida $\left(2.83 \mathrm{~g} \mathrm{CaCO}_{3} \mathrm{~cm}^{-3}\right)$ fabricados a partir de la concha de Tridacna maxima (Carricart-Ganivet y Barnes 2007). Las imágenes digitalizadas de los rayos X se utilizaron para medir los parámetros de crecimiento usando el método de densitometría óptica (Carricart-Ganivet y Barnes 2007). Las bandas de crecimiento coralino de cada imagen se analizaron mediante el software Image J v.1.44 (https://imagej.nih.gov/ij/). La extensión anual $\left(\mathrm{cm}\right.$ año $\left.{ }^{-1}\right)$ se estimó como la distancia lineal entre 2 bandas consecutivas de baja densidad. La densidad media anual $\left(\mathrm{g} \mathrm{CaCO}_{3} \mathrm{~cm}^{-3}\right)$ se definió como el promedio entre el mínimo y máximo de densidad adyacente para cada par de bandas. Finalmente, la tasa anual de calcificación $\left(\mathrm{g} \mathrm{CaCO}_{3} \mathrm{~cm}^{-2}\right.$ año $\left.{ }^{-1}\right)$ se obtuvo mediante el producto de la densidad promedio anual y el crecimiento anual de cada par de bandas (Lough y Barnes 2000).

Con el objetivo de evaluar el efecto estacional que tiene la TSM sobre los parámetros de crecimiento de los corales masivos (Porites y Pavona), se obtuvieron tasas de crecimiento semestrales. Se usó el perfil de densidad generado mediante el método de densitometría óptica (CarricartGanivet y Barnes 2007) utilizado para calcular la tasa de calcificación anual, así como las fechas de recolecta (octubre y noviembre de 2013) y marcaje (alizarina, septiembre y noviembre de 2010), para hacer un análisis esclerocronológico. Las bandas que se situaban por detrás de la marca de 
coral growth areas, we compared in situ data obtained at La Entrega for the period 2010-2011 with the satellite data for the same period. A thermograph, installed at $5 \mathrm{~m}$ depth, recorded temperature at 1-h intervals. Simple linear regression analysis revealed the same pattern and a highly significant positive relation $\left(r^{2}=0.96, P=0.0001\right)$ for the in situ and satellite data. This suggested that the satellite-derived SST data could be used in the analyses including coral growth parameters.

\section{Data analysis}

The relation between the annual growth values (skeletal density, extension rate, and calcification rate) of the massive coral species was analyzed using the Pearson correlation coefficient. Additionally, linear regression models were used to analyze the relation between the SST values and the 6-month growth values. Before these analyses, the assumptions of normality and homoscedasticity of the data were examined. All analyses were performed using $\alpha=0.05$ (Zar 2010).

\section{RESUltS}

The mean $( \pm \mathrm{SD})$ annual growth values (period 2010-2013) are shown in Figure 3. Of the branching corals, Pocillopora damicornis (La Entrega, Oaxaca) had the highest density value $\left(1.78 \pm 0.31 \mathrm{~g} \mathrm{CaCO}_{3} \mathrm{~cm}^{-3}\right)$ and an extension rate of $2.94 \pm 0.32 \mathrm{~cm} \mathrm{yr}^{-1}$, resulting in a calcification rate of $5.23 \pm 1.03 \mathrm{~g} \mathrm{CaCO}_{3} \mathrm{~cm}^{-2} \mathrm{yr}^{-1}$, the highest calcification rate value recorded for the genus. Pocillopora verrucosa (Zacatoso, Guerrero) had the lowest density value $\left(1.47 \pm 0.01 \mathrm{~g} \mathrm{CaCO}_{3} \mathrm{~cm}^{-3}\right)$ and the highest extension rate $\left(3.42 \pm 0.32 \mathrm{~cm} \mathrm{yr}^{-1}\right)$, resulting in a calcification rate of $5.04 \pm 0.44 \mathrm{~g} \mathrm{CaCO}_{3} \mathrm{~cm}^{-2} \mathrm{yr}^{-1}$. Pocillopora meandrina $(\mathrm{La}$ Entrega, Oaxaca) had a mean density of $1.47 \pm 0.09 \mathrm{~g} \mathrm{CaCO}_{3}$ $\mathrm{cm}^{-3}$, extension rate of $2.02 \pm 0.39 \mathrm{~cm} \mathrm{yr}^{-1}$, and calcification rate of $2.99 \pm 0.74 \mathrm{~g} \mathrm{CaCO}_{3} \mathrm{~cm}^{-2} \mathrm{yr}^{-1}$. Pocillopora capitata (La Entrega, Oaxaca) had a mean density of $1.67 \pm 0.07 \mathrm{~g}$ $\mathrm{CaCO}_{3} \mathrm{~cm}^{-3}$, extension rate of $2.92 \pm 0.23 \mathrm{~cm} \mathrm{yr}^{-1}$, and calcification rate of $4.87 \pm 0.14 \mathrm{~g} \mathrm{CaCO}_{3} \mathrm{~cm}^{-2} \mathrm{yr}^{-1}$.

Regarding the massive species, at Zacatoso (Guerrero), Pavona gigantea had the highest values of all 3 growth parameters (density: $1.24 \pm 0.09 \mathrm{~g} \mathrm{CaCO}_{3} \mathrm{~cm}^{-3}$; extension: $0.91 \pm 0.07 \mathrm{~cm} \mathrm{yr}^{-1}$; calcification: $1.13 \pm 0.09 \mathrm{~g} \mathrm{CaCO}_{3} \mathrm{~cm}^{-2}$ $\mathrm{yr}^{-1}$ ), whereas Porites lobata had a mean density of $1.20 \pm$ $0.07 \mathrm{~g} \mathrm{CaCO}_{3} \mathrm{~cm}^{-3}$, extension of $0.60 \pm 0.16 \mathrm{~cm} \mathrm{yr}^{-1}$, and calcification rate of $0.72 \pm 0.22 \mathrm{~g} \mathrm{CaCO}_{3} \mathrm{~cm}^{-2} \mathrm{yr}^{-1}$. At La Entrega (Oaxaca), Porites panamensis had the lowest values of all 3 growth parameters (density: $1.12 \pm 0.08 \mathrm{~g}$ $\mathrm{CaCO}_{3} \mathrm{~cm}^{-3}$; extension: $0.31 \pm 0.07 \mathrm{~cm} \mathrm{yr}^{-1}$; calcification: $0.34 \pm 0.07 \mathrm{~g} \mathrm{CaCO}_{3} \mathrm{~cm}^{-2} \mathrm{yr}^{-1}$ ), and Pavona varians had a mean density of $1.04 \pm 0.07 \mathrm{~g} \mathrm{CaCO}_{3} \mathrm{~cm}^{-3}$, extension rate of alizarina se consideraron como bandas anteriores a 2010 . Considerando que un par de bandas de crecimiento de distinta densidad (alta, baja) representa un año de crecimiento (Barnes y Lough 1993), se hicieron lecturas de cada banda por separado (en lugar de 2, como en el cálculo anual) para, así, obtener los valores semestrales de crecimiento (Fig. 2). La extensión semestral se calculó como la distancia lineal que ocupa cada banda (alta o baja densidad). La densidad semestral promedio se estimó como el promedio entre la densidad mínima y máxima que presentaba cada banda por separado. La tasa de calcificación semestral se calculó como el producto entre la extensión lineal y la densidad promedio semestrales.

\section{Temperatura superficial del mar}

Para cada localidad, se obtuvieron los valores de TSM (máximo, mínimo y promedio mensual \pm desviación estándar) a partir de imágenes del sensor satelital Aqua MODIS, con $4 \mathrm{~km}$ de resolución espacial (http://oceancolor.gsfc.nasa.gov/cgi/13), los cuales comprendieron el periodo de enero de 2007 a diciembre de 2013. Con el fin de comparar la TSM con las bandas de crecimiento de los corales, estos valores se agruparon por semestre considerando el de diciembre a mayo como temporada de invierno y el de junio a noviembre como temporada de verano. Considerando que, debido a la resolución $(4 \times 4 \mathrm{~km})$, los datos de TSM obtenidos por el sensor Aqua MODIS pudieran no representar la temperatura experimentada por los corales en las áreas de crecimiento, se compararon datos de TSM obtenidos in situ

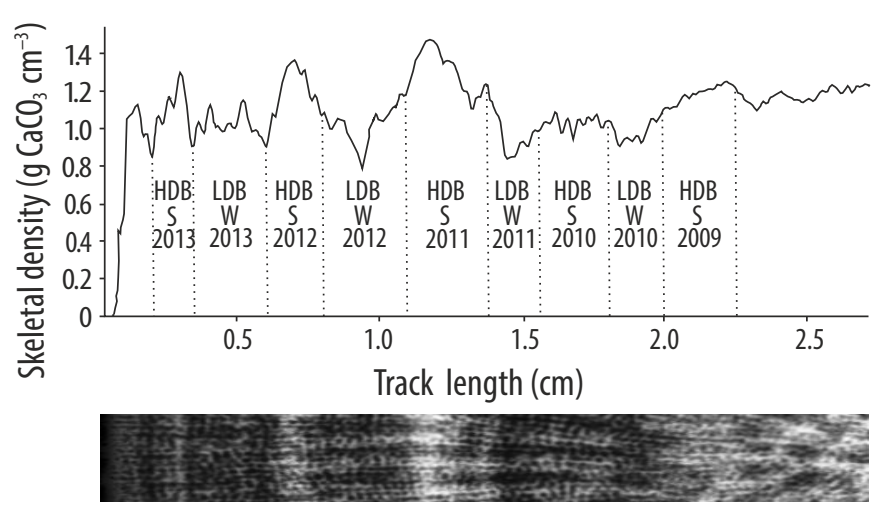

Figure 2. Density values along a transept of a digital X-ray image. To estimate the 6-month (winter/summer) values, the distance occupied by each band along the transept was anchored (dotted line): HDB, high-density band; LDB, low-density band; $\mathrm{S}$, summer; W, winter.

Figura 2. Valores de densidad a lo largo de un transecto de una imagen digital de rayos X. Para estimar los valores semestrales (verano/invierno), se ancló la distancia que ocupaba cada banda a lo largo del transecto (línea punteada): HDB, banda de alta densidad; LDB, banda de baja densidad; S, verano; $\mathrm{W}$, invierno. 

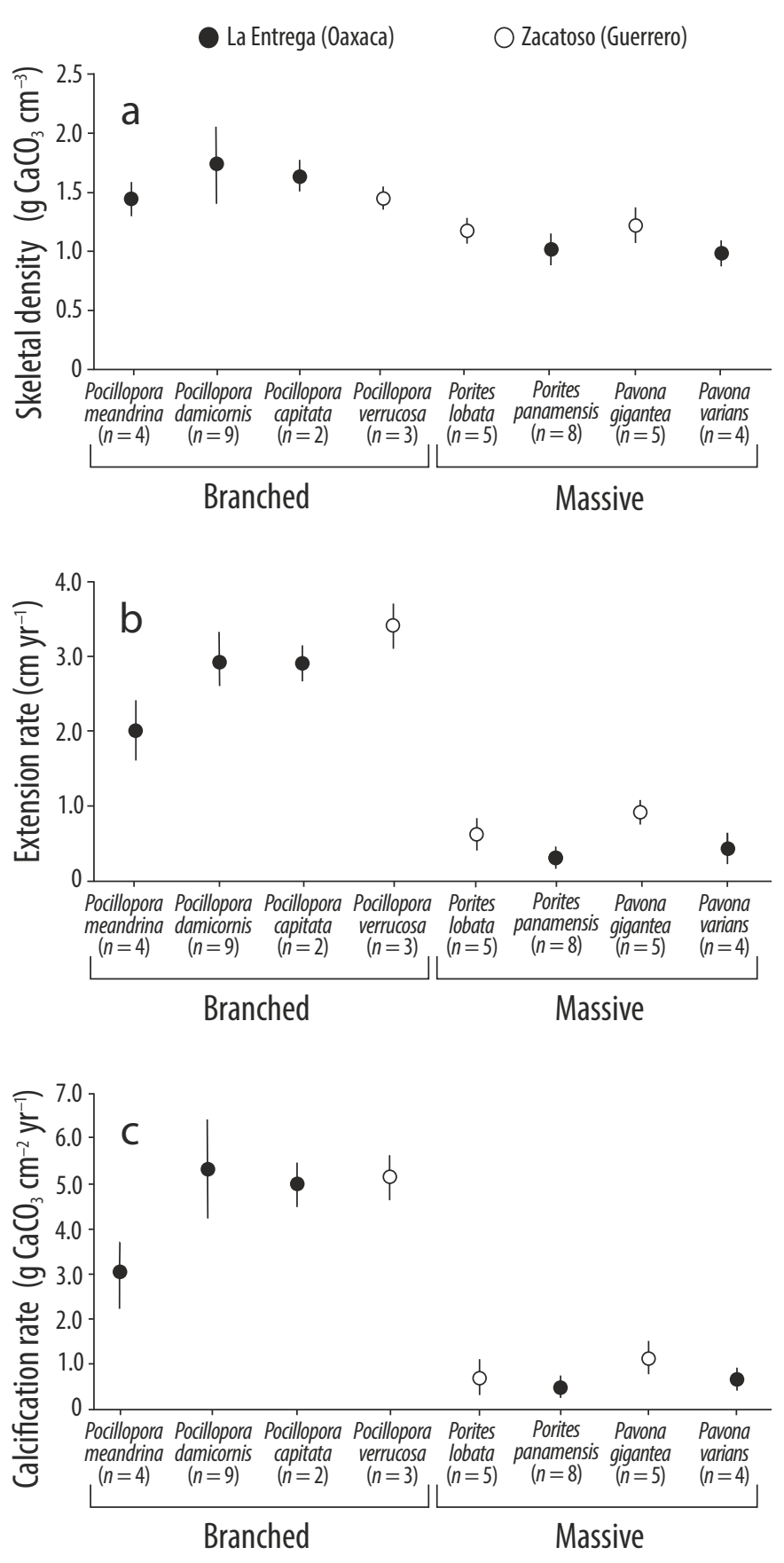

Figure 3. Growth parameters of scleractinian corals on the Pacific coast of southern Mexico for the period 2010-2013: (a) skeletal density $\left(\mathrm{g} \mathrm{CaCO}_{3} \mathrm{~cm}^{-3}\right)$, (b) extension rate $\left(\mathrm{cm} \mathrm{yr}^{-1}\right)$, and (c) calcification rate $\left(\mathrm{g} \mathrm{CaCO}_{3} \mathrm{~cm}^{-2} \mathrm{yr}^{-1}\right)$. Circles represent the mean, vertical lines the standard deviation, and $n$ the sample size.

Figura 3. Parámetros de crecimiento de corales escleractinios en la costa del Pacífico del sur de México durante el periodo 2010-2013: (a) densidad del esqueleto $\left(\mathrm{g} \mathrm{CaCO}_{3} \mathrm{~cm}^{-3}\right)$, (b) tasa de extensión ( $\mathrm{cm}$ año ${ }^{-1}$ y (c) tasa de calcificación $\left(\mathrm{g} \mathrm{CaCO}_{3} \mathrm{~cm}^{-2}\right.$ año $\left.{ }^{-1}\right)$. Los círculos representan la media; las líneas verticales, la desviación estándar; y $n$, el tamaño de muestra. para el periodo 2010-2011 en La Entrega con los datos de TSM obtenidos por el sensor para el mismo periodo. El termógrafo se instaló a $5 \mathrm{~m}$ de profundidad y registró la temperatura a intervalos de $1 \mathrm{~h}$. De acuerdo con un análisis de regresión lineal simple, los datos in situ y los datos satelitales tuvieron el mismo patrón estacional y una relación positiva altamente significativa $\left(r^{2}=0.96, P=0.0001\right)$. Lo anterior sugiere que el uso de los valores de TSM obtenidos mediante imágenes de satélite es adecuado para los análisis que involucran a los parámetros de crecimiento de los corales.

\section{Análisis de datos}

Se evaluó la relación entre los valores anuales de crecimiento coralino (tasa de extensión, densidad del esqueleto y tasa de calcificación) de las especies con crecimiento masivo mediante un análisis de correlación de Pearson. Adicionalmente, se utilizaron modelos de regresión lineal para evaluar la relación entre los valores de TSM y los valores semestrales de crecimiento coralino. Previo a estos análisis, se evaluaron los supuestos de normalidad y homocedasticidad de los datos. Para todos los análisis estadísticos, se consideró un $\alpha=0.05$ (Zar 2010).

\section{RESULTADOS}

Los valores de crecimiento anual promedio ( \pm desviación estándar) (periodo 2010-2013) se muestran en la Figura 3. Respecto a los corales ramificados, Pocillopora damicornis (La Entrega, Oaxaca) presentó el valor promedio más alto de densidad $\left(1.78 \pm 0.31 \mathrm{~g} \mathrm{CaCO}_{3} \mathrm{~cm}^{-3}\right)$ y un crecimiento en extensión de $2.94 \pm 0.32 \mathrm{~cm}^{2}$ año ${ }^{-1}$, lo que resulta en una tasa de calcificación de $5.23 \pm 1.03 \mathrm{~g} \mathrm{CaCO}_{3} \mathrm{~cm}^{-2}$ año $^{-1}$, la más alta registrada para el género. Pocillopora verrucosa (Zacatoso, Guerrero) tuvo el valor de densidad más bajo $\left(1.47 \pm 0.01 \mathrm{~g} \mathrm{CaCO}_{3} \mathrm{~cm}^{-3}\right)$ y la tasa de extensión más alta $\left(3.42 \pm 0.32 \mathrm{~cm} \mathrm{año}^{-1}\right)$ del género, lo que se traduce en una tasa de calcificación de $5.04 \pm 0.44 \mathrm{~g} \mathrm{CaCO}_{3} \mathrm{~cm}^{-2} \mathrm{año}^{-1}$. Pocillopora meandrina (La Entrega, Oaxaca) presentó una densidad de $1.47 \pm 0.09 \mathrm{~g} \mathrm{CaCO}_{3} \mathrm{~cm}^{-3}$, un crecimiento de $2.02 \pm 0.39 \mathrm{~cm}$ año $^{-1}$ y una tasa de calcificación de $2.99 \pm$ $0.74 \mathrm{~g} \mathrm{CaCO}_{3} \mathrm{~cm}^{-2}$ año $^{-1}$. Pocillopora capitata (La Entrega, Oaxaca) mostró una densidad de $1.67 \pm 0.07 \mathrm{~g} \mathrm{CaCO}_{3} \mathrm{~cm}^{-3}$, una extensión de $2.92 \pm 0.23 \mathrm{~cm}^{2}$ año $^{-1} \mathrm{y}$ una calcificación de $4.87 \pm 0.14 \mathrm{~g} \mathrm{CaCO}_{3} \mathrm{~cm}^{-2}$ año ${ }^{-1}$.

Respecto a las especies de coral masivo, en Zacatoso (Guerrero), Pavona gigantea mostró los valores más altos de densidad $\left(1.24 \pm 0.09 \mathrm{~g} \mathrm{CaCO}_{3} \mathrm{~cm}^{-3}\right)$, extensión $(0.91 \pm$ $0.07 \mathrm{~cm}$ año $\left.{ }^{-1}\right)$ y calcificación $\left(1.13 \pm 0.09 \mathrm{~g} \mathrm{CaCO}_{3} \mathrm{~cm}^{-2}\right.$ año $^{-1}$ ), mientras que Porites lobata tuvo una densidad de $1.20 \pm 0.07 \mathrm{~g} \mathrm{CaCO}_{3} \mathrm{~cm}^{-3}$, un crecimiento de $0.60 \pm 0.16 \mathrm{~cm}$ año $^{-1}$ y una tasa de calcificación de $0.72 \pm 0.22 \mathrm{~g} \mathrm{CaCO}_{3} \mathrm{~cm}^{-2}$ año $^{-1}$. Considerando a las especies que se desarrollan en el 
$0.43 \pm 0.07 \mathrm{~cm} \mathrm{yr}^{-1}$, and calcification rate of $0.45 \pm 0.09 \mathrm{~g}$ $\mathrm{CaCO}_{3} \mathrm{~cm}^{-2} \mathrm{yr}^{-1}$.

On average, the massive coral species had 4 pairs of growth bands. This represents a 4-year growth record (2009-2013) per colony and suggests that the studied colonies on average had one year of growth prior to seeding. The correlation analysis of the three annual growth parameters (density, extension, and calcification) revealed a positive and significant relation between extension rate and calcification rate for all the species studied (Porites lobata: $r=0.97$, $P=0.0001$; Pavona gigantea: $r=0.98, P=0.0001$; Porites panamensis: $r=0.98, P=0.0001$; Pavona varians: $r=0.99$, $P=0.0001)$. The correlation between skeletal density and calcification rate was low $(P>0.05)$ for all the species.

A comparison of the SST and growth parameter values (Table 1) revealed that the density values for the Porites and Pavona colonies were positively related to SST (Fig. 4). At Zacatoso, a significant relation between SST and skeletal density was observed for Porites lobata $\left(r^{2}=0.55, P=\right.$ $0.0001)$ and Pavona gigantea $\left(r^{2}=0.62, P=0.0001\right)$. At La Entrega, Porites panamensis $\left(r^{2}=0.36, P=0.01\right)$ and Pavona varians $\left(r^{2}=0.55, P=0.001\right)$ showed a significant positive relation. A low, though significant, correlation between SST and calcification rate was observed for Pavona gigantea $\left(r^{2}=0.19, P<0.5\right)$ and Pavona varians $\left(r^{2}=0.23\right.$, $P<0.5$; Fig. 5). The extension rates for Porites lobata, Porites panamensis, Pavona gigantea, and Pavona varians were not significantly correlated with SST.

\section{DiSCUSSION}

\section{Growth parameters: branching species}

The extension rates reported herein for the 4 Pocillopora species studied ( $P$. capitata, $P$. damicornis, $P$. meandrina, and $P$. verrucosa) fall within the ranges reported in other studies conducted on the Pacific coast of Central America (Glynn 1977, Guzmán and Cortés 1989, Jiménez and Cortés 2003, arrecife La Entrega (Oaxaca), Porites panamensis tuvo los valores más bajos en densidad $\left(1.12 \pm 0.08 \mathrm{~g} \mathrm{CaCO}_{3} \mathrm{~cm}^{-3}\right)$, extensión $\left(0.31 \pm 0.07 \mathrm{~cm}\right.$ año $\left.{ }^{-1}\right)$ y calcificación $(0.34 \pm$ $0.07 \mathrm{~g} \mathrm{CaCO}_{3} \mathrm{~cm}^{-2}$ año $^{-1}$ ), mientras que Pavona varians tuvo una densidad de $1.04 \pm 0.07 \mathrm{~g} \mathrm{CaCO}_{3} \mathrm{~cm}^{-3}$, una extensión de $0.43 \pm 0.07 \mathrm{~cm}^{2}$ año $^{-1} \mathrm{y}$ una calcificación de $0.45 \pm 0.09 \mathrm{~g}$ $\mathrm{CaCO}_{3} \mathrm{~cm}^{-2}$ año $^{-1}$.

Las colonias de los géneros con crecimiento masivo tuvieron en promedio 4 pares de bandas de crecimiento, lo que representa el registro de 4 años (2009-2013) de crecimiento por colonia. Esto sugiere que las colonias estudiadas tenían en promedio un año de crecimiento previo a la siembra. De acuerdo con el análisis de correlación entre los 3 parámetros de crecimiento anuales (extensión, densidad y calcificación), la relación fue positiva y significativa entre la tasa de extensión y la tasa de calcificación para todas las especies estudiadas (Porites lobata: $r=0.97, P=0.0001$; Pavona gigantea: $r=0.98, P=0.0001$; Porites panamensis: $r=0.98, P=0.0001$; y Pavona varians: $r=0.99, P=$ $0.0001)$. La correlación entre la densidad del esqueleto y la tasa de calcificación fue baja $(P>0.05)$ para todas las especies.

Cuando se compararon los registros de la TSM con los de los parámetros de crecimiento (Tabla 1), los valores de densidad del esqueleto de las colonias de los géneros Porites y Pavona se relacionaron positivamente con la TSM (Fig. 4). En Zacatoso, la relación entre la TSM y la densidad del esqueleto fue significativa para Porites lobata $\left(r^{2}=0.55, P=\right.$ $0.0001)$ y Pavona gigantea $\left(r^{2}=0.62, P=0.0001\right)$. En La Entrega, Porites panamensis $\left(r^{2}=0.36, P=0.01\right)$ y Pavona varians $\left(r^{2}=0.55, P=0.001\right)$ mostraron una tendencia positiva significativa. La tasa de calcificación semestral mostró una correlación baja, aunque significativa, con la TSM para Pavona gigantea $\left(r^{2}=0.19, P<0.5\right)$ y Pavona varians $\left(r^{2}=\right.$ 0.23, $P<0.5$; Fig. 5). Las tasas de extensión para Porites lobata, Porites panamensis, Pavona gigantea y Pavona varians no se relacionaron significativamente con la TSM.

Table 1. Mean $( \pm \mathrm{SD})$ 6-month (summer/winter) skeletal density, extension, and calcification values for the massive coral species studied.

Tabla 1. Promedio ( \pm desviación estándar) semestral (verano/invierno) de la densidad del esqueleto, la extensión y la calcificación de las especies de coral masivo estudiadas.

\begin{tabular}{|c|c|c|c|c|c|c|}
\hline Species & Location & $\begin{array}{l}\text { Skeletal density } \\
\left(\mathrm{CaCO}_{3} \mathrm{~cm}^{-3}\right)\end{array}$ & $\begin{array}{l}\text { Extension rate } \\
\qquad\left(\mathrm{cm} \mathrm{yr}^{-1}\right)\end{array}$ & $\begin{array}{c}\text { Calcification rate } \\
\left(\mathrm{g} \mathrm{CaCO}_{3} \mathrm{~cm}^{-2} \mathrm{yr}^{-1}\right)\end{array}$ & Season & $\begin{array}{c}N \\
\text { (bands) }\end{array}$ \\
\hline Porites panamensis & La Entrega & $\begin{array}{l}1.15 \pm 0.04 \\
0.98 \pm 0.05\end{array}$ & $\begin{array}{l}0.18 \pm 0.07 \\
0.12 \pm 0.08\end{array}$ & $\begin{array}{l}0.20 \pm 0.08 \\
0.12 \pm 0.07\end{array}$ & $\begin{array}{l}\text { Summer } \\
\text { Winter }\end{array}$ & $\begin{array}{l}12 \\
13\end{array}$ \\
\hline Pavona varians & La Entrega & $\begin{array}{l}0.95 \pm 0.20 \\
0.82 \pm 0.03\end{array}$ & $\begin{array}{l}0.29 \pm 0.07 \\
0.16 \pm 0.02\end{array}$ & $\begin{array}{l}0.27 \pm 0.07 \\
0.13 \pm 0.01\end{array}$ & $\begin{array}{l}\text { Summer } \\
\text { Winter }\end{array}$ & $\begin{array}{l}9 \\
8\end{array}$ \\
\hline Pavona gigantea & Zacatoso & $\begin{array}{l}1.32 \pm 0.09 \\
0.98 \pm 0.10\end{array}$ & $\begin{array}{l}0.30 \pm 0.15 \\
0.20 \pm 0.09\end{array}$ & $\begin{array}{l}0.41 \pm 0.22 \\
0.19 \pm 0.09\end{array}$ & $\begin{array}{l}\text { Summer } \\
\text { Winter }\end{array}$ & $\begin{array}{l}10 \\
10\end{array}$ \\
\hline
\end{tabular}




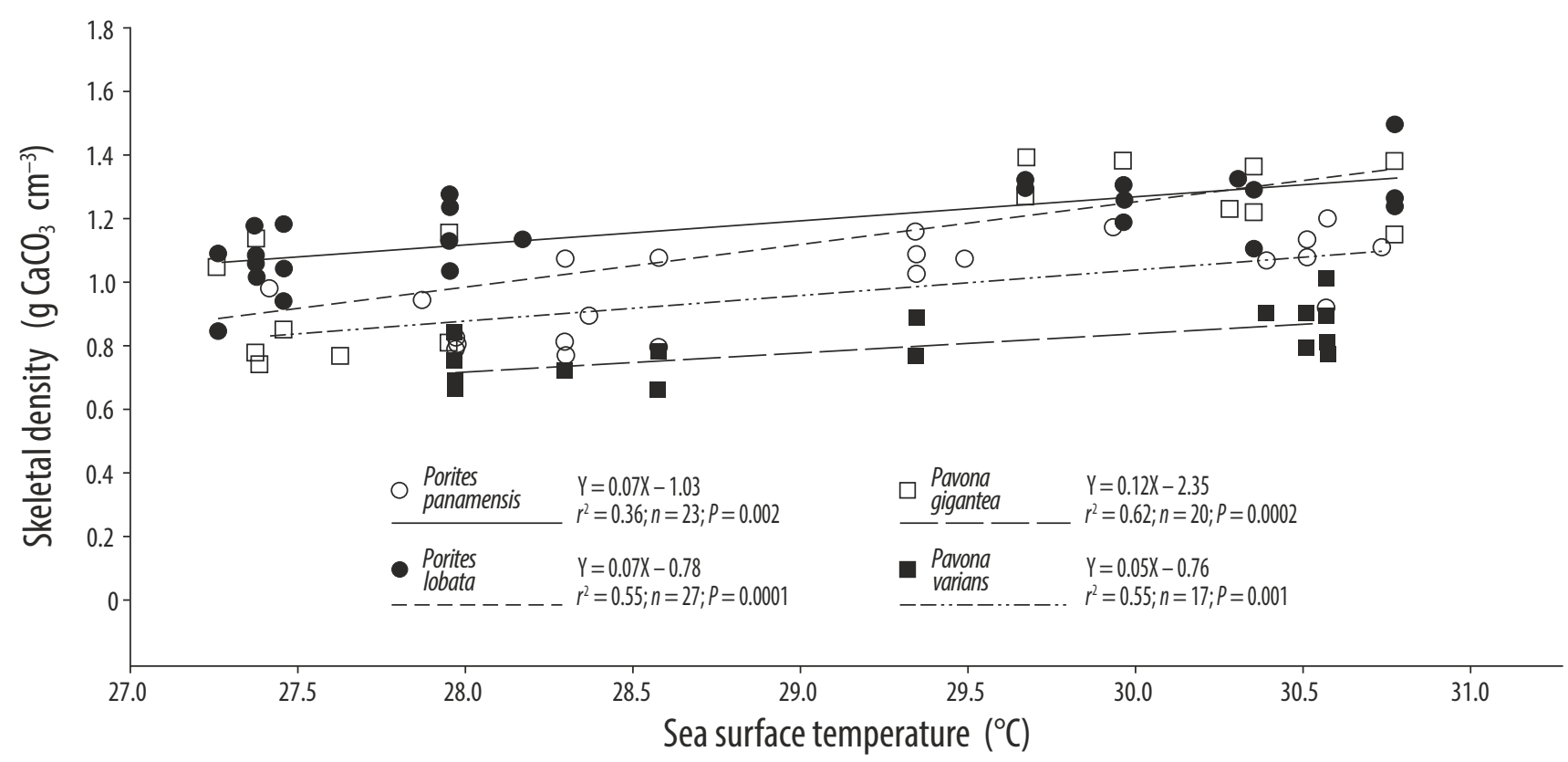

Figure 4. Relation between skeletal density and sea surface temperature in the massive corals collected on the Pacific coast of southern Mexico.

Figura 4. Relación entre la densidad del esqueleto y la temperatura superficial del mar en los corales masivos recolectados en la costa del Pacífico del sur de México.

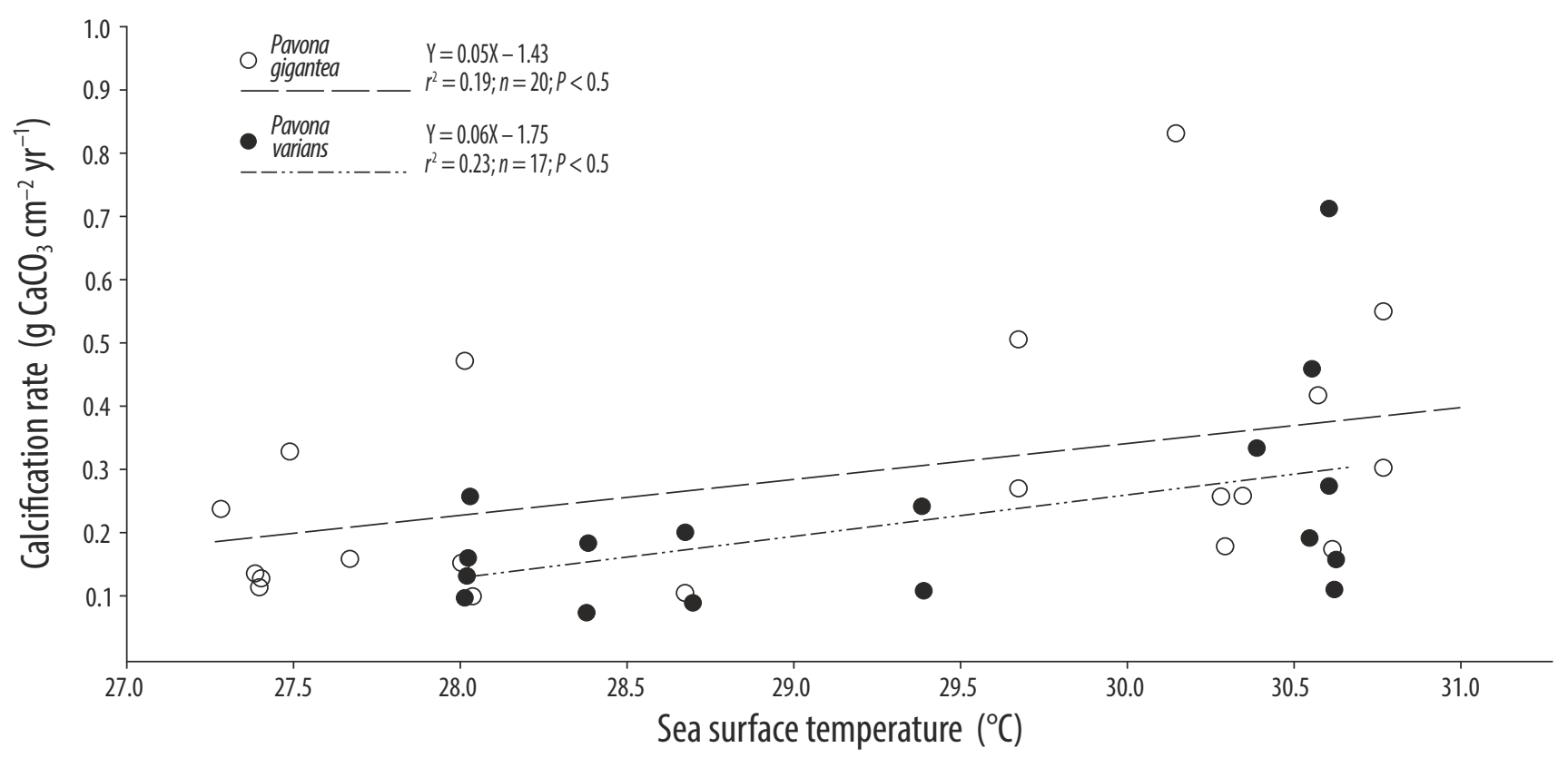

Figure 5. Relation between calcification rate and sea surface temperature in the massive corals collected on the Pacific coast of southern Mexico.

Figura 5. Relación entre la tasa de calcificación y la temperatura superficial de mar en los corales masivos recolectados en la costa del Pacífico del sur de México. 
Manzello 2010). Considering that the environmental conditions at our study sites have been described as unfavorable for coral growth (e.g., upwelling, SST fluctuations, low $\Omega_{\text {aragonite; Reyes-Bonilla et al. 2002, Cupul-Magaña and }}$ Calderón-Aguilera 2008, Chapa-Balcorta et al. 2015), they must not be sufficiently adverse or extreme to negatively influence the calcification process of Pocillopora spp. and, in turn, their contribution of calcium carbonate to reef development. Except for one reef (Morros del Cerro Colorado) off Ixtapa, Guerrero (López-Pérez et al. 2012), where Porites lobata is the species that contributes the most to coral growth and reef structure, the reefs in our study area are relatively small, have low species diversity, and are primarily formed by Pocillopora spp. (Cortés 2003, Reyes-Bonilla 2003).

Among the factors that may explain the predominance of Pocillopora spp. in the region is their symbiotic relationship with stress-tolerant Symbiodinium clade D (LaJeunesse et al. 2010, Walther-Mendoza et al. 2016), which could prove advantageous during El Niño events (Carriquiry et al. 2001, Reyes-Bonilla et al. 2002, Baker et al. 2004, López-Pérez et al. 2016). Also, the ability of Pocillopora spp. to tolerate increased nutrient levels, mainly phosphorus and ammonium (Stambler et al. 1991, Muller-Parker 1994), as occurs during seasonal upwelling events in the region, may also be advantageous. Two other factors may also contribute to the predominance of this genus in the region: (1) the ability of pocilloporid corals to reproduce asexually via fragmentation and (2) the high extension and calcification rates of Pocillopora spp. In both the Indo-Pacific and eastern Pacific (Carriquiry and Reyes-Bonilla 1997, Ayre et al. 1997), corals belonging to the genus Pocillopora have been found to easily colonize other reef areas after their branches are detached by waves and cyclones. If they are not buried (López-Pérez et al. 2007), the broken-off fragments become attached to the substrate and continue to develop, allowing branching corals to have greater success in competition for space than the species with low probability of fragmentation (Glynn and Ault 2000, Reyes-Bonilla 2003, Reyes-Bonilla et al. 2013). Pocillopora spp. have relatively high extension and calcification rates compared to Porites spp. and Pavona spp. in the study area (Fig. 3) and to Pocillopora spp. growing at other sites (Table 2).

\section{Growth parameters: massive species}

The calcification rates obtained for the massive coral species are, for the most part, lower than those previously recorded by other authors at other latitudes (Table 2). In the case of Porites panamensis, our value was 32\% lower than that reported for Concepción Bay in the Gulf of California (0.5 $\mathrm{g} \mathrm{CaCO}_{3} \mathrm{~cm}^{-2} \mathrm{yr}^{-1}$; Cabral-Tena et al. 2013) and for the Marietas Islands off the Pacific coast of central Mexico (0.49 $\pm 0.16 \mathrm{~g} \mathrm{CaCO}_{3} \mathrm{~cm}^{-2} \mathrm{yr}^{-1}$; Norzagaray-López et al. 2013), and up to $74.8 \%$ lower than that reported for La Paz Bay (Cabral-Tena et al. 2013) and Cabo Pulmo

\section{DISCUSIÓN}

\section{Parámetros de crecimiento: especies ramificadas}

Las tasas de extensión de las especies de Pocillopora (P. capitata, $P$. damicornis, $P$. meandrina y $P$. verrucosa) registradas en este trabajo están dentro del intervalo reportado por otros estudios realizados en la costa del Pacífico de Centroamérica (Glynn 1977, Guzmán y Cortés 1989, Jiménez y Cortés 2003, Manzello 2010). Considerando que las condiciones ambientales en las 2 regiones donde se desarrolló este estudio han sido descritas como desfavorables para el crecimiento coralino (e.g., surgencias, oscilaciones en la TSM, baja $\Omega_{\text {aragonita }}$; Reyes-Bonilla et al. 2002, Cupul-Magaña y Calderón-Aguilera 2008, Chapa-Balcorta et al. 2015), éstas no deben ser lo suficientemente agudas o extremas como para influenciar negativamente el proceso de calcificación de Pocillopora y, en última instancia, la contribución de carbonato de calcio del género al desarrollo arrecifal. Excepto un arrecife en la zona de Ixtapa (Morros del Cerro Colorado, Guerrero; López-Pérez et al. 2012), donde Porites lobata contribuye mayormente a la estructura y crecimiento arrecifal, los arrecifes del área de estudio se caracterizan por ser relativamente pequeños, tener baja diversidad de especies y estar construidos mayoritariamente por especies del genero Pocillopora (Cortés 2003, Reyes-Bonilla 2003).

Uno de los factores que podrían explicar la dominancia de las especies de Pocillopora en la región es la relación simbiótica de este género con clados tipo D de Symbiodinium tolerantes al estrés térmico (LaJeunesse et al. 2010, WaltherMendoza et al. 2016), que podría resultar ventajosa durante eventos El Niño (Carriquiry et al. 2001, Reyes-Bonilla et al. 2002, Baker et al. 2004, López-Pérez et al. 2016). Además, la capacidad de Pocillopora spp. para tolerar el aumento en las concentraciones de nutrientes, principalmente fósforo $\mathrm{y}$ amonio (Stambler et al. 1991, Muller-Parker 1994), que emergen durante las surgencias estacionales que ocurren en la región pudiera también ser ventajoso. Hay otros 2 elementos que podrían contribuir a la dominancia del género en la región: (1) su capacidad para reproducirse asexualmente mediante fragmentación y (2) sus altas tasas de extensión y calcificación. Tanto en el Indo-Pacífico como en el Pacífico oriental (Carriquiry y Reyes-Bonilla 1997, Ayre et al. 1997), se ha observado que las especies del género Pocillopora colonizan fácilmente otras áreas arrecifales después de que sus ramas se desprenden por efecto del oleaje o ciclones; en caso de no ser enterrados (López-Pérez et al. 2007), los fragmentos así generados se unen al sustrato y continúan desarrollándose, lo que incrementa el éxito competitivo por espacio de las especies ramificadas con respecto a las especies con poca probabilidad de fragmentarse (Glynn y Ault 2000, Reyes-Bonilla 2003, Reyes-Bonilla et al. 2013). Pocillopora spp. tiene tasas de extensión y calcificación relativamente altas comparadas con las observadas en Porites spp. y Pavona spp. en el área de estudio (Fig. 3) y en Pocillopora spp. que se desarrollan en otros sitios (Tabla 2). 


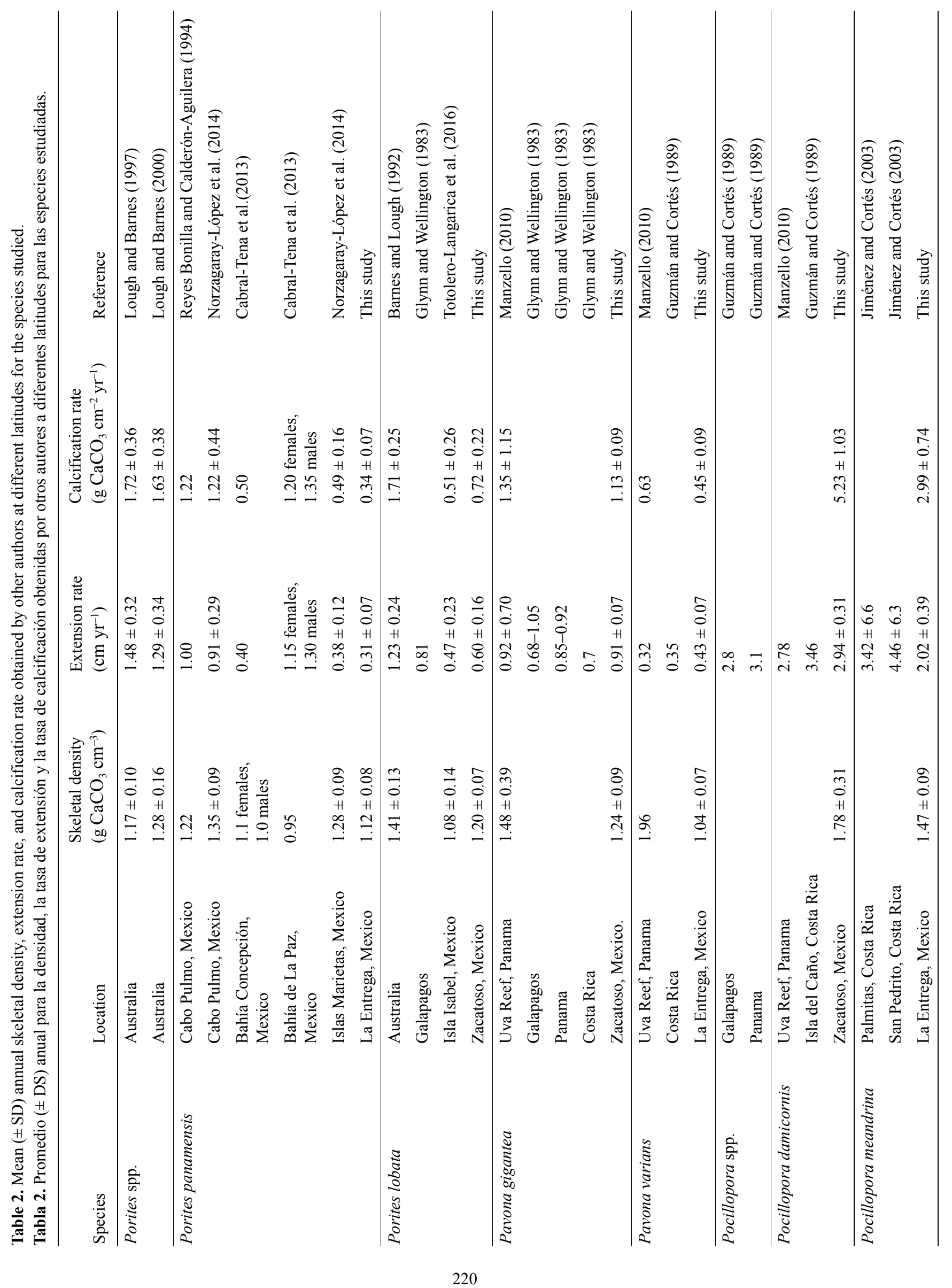


(Reyes-Bonilla and Calderón-Aguilera 1994) in the Gulf of California. All 3 growth parameter values recorded in this study for Porites lobata were slightly higher than those reported by Tortolero-Langarica et al. (2016) for free-living coral (i.e., rhodoliths) off Isabel Island (Nayarit); thus, the corals growing off Ixtapa (this study) have extension values that are $21.6 \%$ higher $\left(0.60 \pm 0.16 \mathrm{~cm} \mathrm{yr}^{-1}\right)$, they are $10 \%$ denser $\left(1.20 \pm 0.07 \mathrm{~g} \mathrm{CaCO}_{3} \mathrm{~cm}^{-3}\right)$, and they calcify, on average, $29.1 \%$ more $\left(0.72 \pm 0.22 \mathrm{~g} \mathrm{CaCO}_{3} \mathrm{~cm}^{-2} \mathrm{yr}^{-1}\right)$. Nonetheless, the calcification rate obtained for the species is $57.8 \%$ lower than that recorded by Barnes and Lough (1992) in the Great Barrier Reef, Australia $\left(1.71 \pm 0.25 \mathrm{~g} \mathrm{CaCO}_{3} \mathrm{~cm}^{-2}\right.$ $\left.\mathrm{yr}^{-1}\right)$. Likewise, the calcification rate obtained for Pavona gigantea was $17 \%$ lower than that reported for La Uva reef in Panama (1.35 $\mathrm{g} \mathrm{CaCO}_{3} \mathrm{~cm}^{-2} \mathrm{yr}^{-1}$; Manzello 2010). Finally, the calcification rate for Pavona varians was $28.57 \%$ lower than that recorded by Manzello (2010) in Panama $\left(0.63 \mathrm{~g} \mathrm{CaCO}_{3} \mathrm{~cm}^{-2} \mathrm{yr}^{-1}\right)$.

The relatively low calcification values reported herein for the massive species are the result of a low mean extension rate. The highest extension rates of each colony were recorded during the years that the highest calcification values were recorded, suggesting that the Porites panamensis, Porites lobata, Pavona gigantea, and Pavona varians colonies that develop off the Pacific coast of southern Mexico invest more resources into extension than into density, as a result of a positive relation between extension rate and calcification rate (Lough and Barnes 2000, Carricart-Ganivet et al. 2007, Cabral-Tena et al. 2013). These species appear to adopt an extension growth strategy that allows them to compete for space and occupy a greater area in as little time as possible (Lough and Barnes 2000). This is the same strategy adopted by the branching species in the region (see previous section). Nevertheless, the skeletal extension values of any coral belonging to the genus Pocillopora are sensibly higher than those observed for any massive species; hence, the pocilloporid corals in the region contribute most strongly $(>90 \%)$ to the construction of the reef structure, whereas the contribution of Pavona spp. (>5\%) and Porites spp. ( $>1 \%)$ is marginal (Glynn and Leyte-Morales 1997, Carriquiry et al. 2001, López-Pérez et al. 2012).

\section{Relation between coral growth and SST}

Even though the mechanisms and timing of high- and low-density band formation on coral skeletons and the factors that regulate coral calcification are still under discussion, the following variables are known to influence these processes: light (Buddemeier 1974, Wellington and Glynn 1983, Falkowski 2000, Yentsch et al. 2002), sedimentation (Carricart-Ganivet and Merino 2001), nutrient levels (Lough et al. 1999), $\Omega_{\text {aragonite }}$ (Kleypas et al 1999, Gattuso et al. 1998, Langdon et al. 2000, Marubini et al. 2001), and SST (Dodge et al. 1974; Carricart-Ganivet 2004, 2007; Cabral-Tena et al.

\section{Parámetros de crecimiento: especies masivas}

Los valores de la tasa de calificación obtenidos para las especies de coral masivo, en su mayoría, son menores que aquellos reportados previamente por otros autores y para otras latitudes (Tabla 2). En el caso de Porites panamensis, el valor fue $32 \%$ menor para el área de estudio que el valor reportado para bahía Concepción $\left(0.5 \mathrm{~g} \mathrm{CaCO}_{3} \mathrm{~cm}^{-2}\right.$ año-1) en el golfo de California (Cabral-Tena et al. 2013) y para las islas Marietas $\left(0.49 \pm 0.16 \mathrm{~g} \mathrm{CaCO}_{3} \mathrm{~cm}^{-2}\right.$ año $\left.^{-1}\right)$ en la costa del Pacífico de la parte central de México (Norzagaray-López et al. 2013), y hasta $74.8 \%$ menor que el valor registrado para bahía de La Paz (Cabral-Tena et al. 2013) y cabo Pulmo (Reyes-Bonilla y Calderón-Aguilera 1994). Respecto a Porites lobata, los valores de los 3 parámetros de crecimiento registrados en el presente estudio fueron ligeramente mayores respecto a lo observado por Tortolero-Langarica et al. (2016) para corales de vida libre (i.e., rodolitos) en isla Isabel frente a Nayarit; por tanto, los corales que se desarrollan en Ixtapa (este estudio) son 21.6\% más extensos $\left(0.60 \pm 0.16 \mathrm{~cm}^{a n ̃ o}{ }^{-1}\right)$ y $10 \%$ más densos $(1.20 \pm 0.07 \mathrm{~g}$ $\left.\mathrm{CaCO}_{3} \mathrm{~cm}^{-3}\right)$, y calcifican, en promedio, $29.1 \%$ más $(0.72 \pm$ $0.22 \mathrm{~g} \mathrm{CaCO}_{3} \mathrm{~cm}^{-2}$ año $^{-1}$ ). No obstante, Porites lobata posee una tasa de calcificación $57.8 \%$ menor que aquella reportada por Barnes y Lough (1992) para la gran barrera arrecifal de Australia $\left(1.71 \pm 0.25 \mathrm{~g} \mathrm{CaCO}_{3} \mathrm{~cm}^{-2} \mathrm{año}^{-1}\right)$. Igualmente, Pavona gigantea tiene una tasa de calcificación $17 \%$ menor que aquella reportada para el arrecife La Uva (1.35 $\mathrm{g} \mathrm{CaCO}_{3} \mathrm{~cm}^{-2}$ año $^{-1}$ ) en Panamá (Manzello 2010). Pavona varians mostró una calcificación menor (28.57\%) que lo previamente reportado por Manzello (2010) para Panamá $\left(0.63 \mathrm{~g} \mathrm{CaCO}_{3} \mathrm{~cm}^{-2} \mathrm{año}^{-1}\right)$.

Los relativamente bajos valores de calcificación de las especies con crecimiento masivo registrados durante el presente estudio resultaron de una reducida tasa de extensión promedio. En los años de mayor extensión de cada colonia, se registró el valor más alto de calcificación, lo que sugiere que las colonias de Porites panamensis, Porites lobata, Pavona gigantea y Pavona varians que se desarrollan en la costa del Pacífico del sur de México invierten más recursos en extensión que en densidad, resultado de una relación positiva entre la tasa de extensión y la tasa de calcificación (Lough y Barnes 2000, Carricart-Ganivet et al. 2007, CabralTena et al. 2013). Lo observado sugiere que estas especies adoptan una estrategia de crecimiento de extensión, lo que les permite competir por espacio y, así, ocupar una mayor área en el menor tiempo posible (Lough y Barnes 2000). Ésta es la misma estrategia que adoptan las especies ramificadas en la región (ver sección previa). No obstante, los valores de extensión esqueletal de cualquier especie de Pocillopora son sensiblemente mayores que los observados para cualquier especie con crecimiento masivo; por tanto, los pocilopóridos en la región contribuyen mayoritariamente $(>90 \%)$ a la construcción de la estructura arrecifal, mientras que Pavona spp. 
2013; Norzagaray-López et al. 2013). In particular, SST has been observed to substantially affect coral calcification rates (Dodge et al. 1974, Veron 1995, Lough and Barnes 2000, Cruz-Piñón et al. 2003, Carricart-Ganivet 2004, CarricartGanivet et al. 2012). Cabral-Tena et al. (2013) and Norzagaray-López et al. (2013) reported that SST affects skeletal density and extension of massive corals on the Pacific coast of Mexico. As extension is the main growth strategy of all the massive corals studied (see previous section), a relation between extension and SST would be expected; however, the results do not indicate that there is a significant relation $(P>0.05)$ between these two variables, which suggests that skeletal extension may be regulated by another environmental variable not considered in this region of southern Mexico (Guerrero and Oaxaca).

A significant relation was observed between skeletal density and SST in all the massive species studied, indicating that maximum annual skeletal density occurs when the temperature is higher. This finding concurs with Barnes and Lough (1992) who reported that the high-density bands of Porites corals in Australia formed in summer. Regarding the relation between calcification rate and SST, in Pavona gigantea and Pavona varians (Fig. 5) maximum calcification rate occurred above $29^{\circ} \mathrm{C}$. Other studies, however, have reported that it occurs at $26-28^{\circ} \mathrm{C}$ (Edmunds 2005, Cooper et al. 2008). This difference could be attributed to the adaptation of reef-building corals to the local environmental conditions they experience off Mexico's Pacific coast. There is evidence of the acclimatization of coral populations to lower or higher local and regional temperatures (Kleypas et al. 1999) than those reported here, and that maximum calcification levels can occur at different temperature ranges probably in concordance with different symbionts (Baker 2004, Jones et al. 2008, LaJeunesse et al. 2010, Walther-Mendoza et al. 2016).

Finally, even though the sampling size for some species (e.g., P. varians) was small and the results should be interpreted with caution, this study reports, for the first time, the density, extension rate, and calcification rate of the main reefbuilding corals on the Pacific coast of southern Mexico. The results are relevant and when they are analyzed in a regional context (i.e., eastern Pacific) they provide insight into the large-scale processes that regulate the coral calcification parameters, in particular those related to $\Omega_{\text {aragonite }}$ and $\mathrm{pH}$. The results of this study, together with studies on the carbonate system in this region (Chapa-Balcorta et al. 2015), are essential in order to conduct real-time studies in the near future of the effects of $\mathrm{pH}$ and $\Omega_{\text {aragonite }}$ on the development of reefforming corals.

\section{ACKNOWLEDGMENTS}

This study was financed by grants from the National Council for Science and Technology (CONACYT, Mexico, Basic Science project 236654) and PRODEP UAM-PTC
$(>5 \%)$ y Porites spp. ( $>1 \%)$ lo hacen de manera marginal (Glynn y Leyte-Morales 1997, Carriquiry et al. 2001, LópezPérez et al. 2012).

\section{Relación entre el crecimiento y la TSM}

Aunque se siguen discutiendo los mecanismos y el tiempo en que se forman las bandas de alta y baja densidad en los esqueletos de los corales y los factores que regulan la calcificación coralina, se reconoce que variables tales como la luz (Buddemeier 1974, Wellington y Glynn 1983, Falkowski 2000, Yentsch et al. 2002), la sedimentación (CarricartGanivet y Merino 2001), la concentración de nutrientes (Lough et al. 1999), $\Omega_{\text {aragonita }}$ (Gattuso et al. 1998, Kleypas et al. 1999, Langdon et al. 2000, Marubini et al. 2001) y la TSM (Dodge et al. 1974; Carricart-Ganivet 2004, 2007; Cabral-Tena et al. 2013; Norzagaray-López et al. 2013) influyen estos procesos. En particular, se ha observado que la TSM afecta sustancialmente la tasa de calcificación de los corales (Dodge et al. 1974, Veron 1995, Lough y Barnes 2000, Cruz-Piñón et al. 2003, Carricart-Ganivet 2004, Carricart-Ganivet et al. 2012). Cabral-Tena et al. (2013) y Norzagaray-López et al. (2013) reportaron que la TSM tiene influencia sobre la extensión y densidad del esqueleto de los corales masivos de la costa del Pacífico de México. Considerando que la principal estrategia de crecimiento en todas las especies masivas estudiadas es la extensión (ver sección anterior), se esperaría encontrar una relación entre la extensión y la TSM. Sin embargo, los resultados no indican que exista relación significativa $(P>0.05)$ entre estas 2 variables, lo que sugiere que la extensión pudiese estar regulada por alguna otra variable ambiental no considerada en esta zona del sur de México (Guerreo y Oaxaca).

En el caso de la densidad del esqueleto, se observó una relación significativa con la TSM en todas las especies con crecimiento masivo, lo que indica que la máxima densidad anual del esqueleto se alcanza cuando la temperatura es alta. Lo anterior concuerda con lo observado para el género Porites en Australia por Barnes y Lough (1992), quienes reportaron bandas de alta densidad formadas durante el verano. En cuanto a la relación entre la tasa de calcificación y la TSM, Pavona gigantea y Pavona varians (Fig. 5) mostraron puntos máximos de calcificación a temperaturas por arriba de $\operatorname{los} 29^{\circ} \mathrm{C}$, lo que difiere con lo encontrado en otros estudios donde se registra una temperatura de máxima calcificación en el intervalo de 26 a $28^{\circ} \mathrm{C}$ (Edmunds 2005, Cooper et al. 2008). Esta diferencia puede resultar de la adaptación local de los corales constructores de arrecifes a las condiciones ambientales que experimentan los organismos en la costa del Pacífico del sur de México. No es raro encontrar evidencias de poblaciones de corales aclimatadas a temperaturas locales o regionales más bajas o más elevadas (Kleypas et al. 1999) que las reportadas aquí, y que podrían alcanzar niveles de calcificación máximos a distintos intervalos de temperatura, probablemente en concordancia con 
(509) to ALP. We thank Omar Valencia-Méndez (UAM-I) for his support and 2 anonymous reviewers for their valuable comments that helped to improve this paper.

English translation by Christine Harris.

\section{REFERENCES}

Atkinson MJ, Bilger RW. 1992. Effects of water velocity on phosphate uptake in coral reef-flat communities. Limnol. Oceanogr. 37: 273-279.

Atkinson MJ, Kotler E, Newton P. 1994. Effects of water velocity on respiration, calcification, and ammonium uptake of a Porites compressa community. Pac. Sci. 48: 296-303.

Ayre DJ, Hughes TP, Standish RJ. 1997. Genetic differentiation, reproductive mode, and gene flow in the brooding coral Pocillopora damicornis along the Great Barrier Reef, Australia. Mar. Ecol. Prog. Ser. 159: 175-187.

Baker AC. 2004. Symbiont diversity on coral reefs and its relationship to bleaching resistance and resilience. In: Coral Health and Disease. Springer, Berlin, Heidelberg, pp. 177-194.

Baker AC, Starger CJ, McClanahan TR, Glynn PW. 2004. Coral reefs: Corals' adaptive response to climate change. Nature 430: 741.

http://dx.doi.org/10.1038/430741a

Barnes DJ. 1972. The structure and formation of growth-ridges in Scleractinian coral skeletons. Proc. R. Soc. Lond. (Biol. Sci.) 182: 331-350.

Barnes DJ, Lough JM. 1992. Systematic variations in the depth of skeleton occupied by coral tissue in massive colonies of Porites from the Great Barrier Reef. J. Exp. Mar. Biol. Ecol. 159: $113-128$.

Barnes DJ, Lough JM. 1993. On the nature and causes of density banding in massive coral skeletons. J. Exp. Mar. Biol. Ecol. 167: 91-108.

Barnes DJ, Lough JM. 1999. Porites growth characteristics in a changed environment: Misima Island, Papua New Guinea. Coral Reefs 18: 213-218.

Brown BE, Scoffin TP. 1986. Measuring growth rates of reef corals as an indicator of the effects of pollution and environmental disturbance. In: Brown BE (ed.), Human Induced Damage to Coral Reefs. UNESCO Rep. Mar. Sci. 40: 12-24.

Buddemeier RW. 1974. Environmental controls over annual and lunar monthly cycles in hermatypic coral calcification. Proc. 2nd Int. Coral Reef Symp. 2: 259-26.

Buddemeier RW, Kleypas JA, Aronson RB. 2004. Coral reefs and global climate change: Potential contributions of climate change to stresses on coral reef ecosystems. Pew Center on Global Climate Change, Arlington, $44 \mathrm{pp}$.

Cabral-Tena R, Reyes-Bonilla H, Lluch-Cota S, Paz-García D, Calderón-Aguilera LE, Norzagaray-López O, Balart E. 2013. Different calcification rates in males and females of the coral Porites panamensis in the Gulf of California. Mar. Ecol. Prog. Ser. 476: 1-8. http://dx.doi.org/ 10.3354/meps10269

Calderón-Aguilera LE, Reyes-Bonilla H, Carriquiry JD. 2007. El papel de los arrecifes coralinos en el flujo de carbono en el océano: Estudios en el Pacífico mexicano. In: Hernández-Torre B, Gaxiola-Castro G (eds.), Carbono en Ecosistemas Acuáticos de México. SEMARNAT/INE, CICESE, México, pp. 215-226.

Carricart-Ganivet JP. 2004. Sea surface temperature and the growth of the West Atlantic reef building coral Montastraea annularis. J. Exp. Mar. Biol. Ecol. 302: 249-260. distintos tipos de simbiontes (Baker 2004, Jones et al. 2008, LaJeunesse et al. 2010, Walther-Mendoza et al. 2016).

Finalmente, el tamaño de muestra fue pequeño para algunas especies (e.g., Pavona varians), por lo que los resultados deben tomarse con cautela; no obstante, este estudio reporta, por primera vez, las tasas de extensión, densidad y calcificación de las principales especies de corales constructoras de arrecife de la costa del Pacífico del sur de México. Los resultados son, en virtud de sí mismos, relevantes pero cuando son analizados en un contexto regional (i.e., Pacífico oriental), ofrecen indicios respecto a los procesos que a gran escala regulan los parámetros de calcificación de los corales, en particular aquellos relacionados con $\Omega_{\text {aragonita }}$ y el pH. Así, los resultados de la presente contribución, en conjunto con estudios del sistema de carbonatos en esta región (ChapaBalcorta et al. 2015), son fundamentales para en un futuro cercano estudiar en tiempo real los efectos causados por el $\mathrm{pH}$ y $\Omega_{\text {aragonita }}$ en el desarrollo de los corales formadores de arrecifes.

\section{Agradecimientos}

Los recursos para realizar este proyecto fueron aportados por los fondos Ciencia Básica, del Consejo Nacional de Ciencia y Tecnología (CONACYT, México; no. 236654), y PRODEP UAM-PTC (509) otorgados a ALP. Se agradece el apoyo de Omar Valencia-Méndez (UAM-I) y las observaciones de 2 revisores anónimos que ayudaron a mejorar el manuscrito.

Carricart-Ganivet JP. 2007. Annual density banding in massive coral skeletons: Result of growth strategies to inhabit reefs with high microborers' activity? Mar. Biol. 153: 1-5.

Carricart-Ganivet JP, Barnes DJ. 2007. Densitometry from digitized images of X-radiographs: Methodology for measurement of coral skeletal density. J. Exp. Mar. Biol. Ecol. 344: 67-72.

Carricart-Ganivet JP, Beltrán-Torres AU, Merino M, Ruiz-Zarate MA. 2000. Skeletal extension, density and calcification rate of the reef building coral Montastraea annularis (Ellis and Solander) in the Mexican Caribbean. Bull. Mar. Sci. 66: 215-224.

Carricart-Ganivet JP, Cabanillas-Terán N, Cruz-Ortega I, Blanchon P. 2012. Sensitivity of calcification to thermal stress varies among genera of massive reef-building corals. PLOS One 7(3): e32859.

http://dx.doi.org/10.1371/journal.pone.0032859

Carricart-Ganivet JP, Lough JM, Barnes DJ. 2007. Growth and luminescence characteristics in skeletons of massive Porites from a depth gradient in the central Great Barrier Reef. J. Exp. Mar. Biol. Ecol. 351: 27-36.

Carricart-Ganivet JP, Merino M. 2001. Growth responses of the reef-building coral Montastraea annularis along a gradient of continental influence in the southern Gulf of Mexico. Bull. Mar. Sci. 68: 133-146.

Carriquiry JD, Cupul-Magaña AL, Rodríguez-Zaragoza F, MedinaRosas P. 2001. Coral bleaching and mortality in the Mexican Pacific during the 1997-98 El Niño and prediction from a remote sensing approach. Bull. Mar. Sci. 69: 237-249. 
Carriquiry JD, Reyes-Bonilla H. 1997. Community structure and geographic distribution of the coral reefs of Nayarit, Mexican Pacific $=$ Estructura de la comunidad y distribución geográfica de los arrecifes coralinos de Nayarit, Pacífico de México. Cienc. Mar. 23(2): 227-248.

Chalker B, Barnes D, Isdale P. 1985. Calibration of X-ray densitometry for the measurement of coral skeletal density. Coral Reefs 4: 95-100.

Chapa-Balcorta C, Hernández-Ayón JM, Durazo R, Beier E, Alin SR, López-Pérez A. 2015. Influence of post-Tehuano oceanographic processes in the dynamics of the $\mathrm{CO}_{2}$ system in the Gulf of Tehuantepec, Mexico. J. Geophys. Res. (Oceans) 120(12): 7752-7770. http://dx.doi.org/10.1002/2015JC011249

Cooper TF, De'Ath G, Fabricius KE, Lough JM. 2008. Declining coral calcification in massive Porites in two nearshore regions of the northern Great Barrier Reef. Global Change Biol. 14: 529-538.

Cortés J. 2003. Latin American Coral Reefs. Elsevier, Amsterdam, $497 \mathrm{pp}$.

Cruz-Piñón G, Carricart-Ganivet JP, Espinoza-Avalos J. 2003. Monthly skeletal extension rates of the hermatypic corals Montastraea annularis and Montastrae faveolata: Biological and environmental controls. Mar. Biol. 143: 491-500.

Cupul-Magaña A, Calderón-Aguilera L. 2008. Cold water bleaching at Islas Marietas National Park, Nayarit, Mexico. 15th National Oceanography Conference, 13-18 October 2008, Veracruz, Mexico.

Dodge RE, Aller RC, Thomson J. 1974. Coral growth related to resuspension of bottom sediments. Nature 247: 574-577.

Dodge RE, Brass GW. 1984. Skeletal extension, density and calcification of the reef coral, Montastrea annularis: St. Croix, US Virgin Islands. Bull. Mar. Sci. 34: 288-307.

Edmunds PJ. 2005. Effect of elevated temperature on aerobic respiration of coral recruits. Mar. Biol. 146: 655-663.

Fabricius KE. 2005. Effects of terrestrial runoff on the ecology of corals and coral reefs: Review and synthesis. Mar. Pollut. Bull. 50: $125-146$.

Falkowski P. 2000. The global carbon cycle: A test of our knowledge of earth as a system. Science 5490: 291-296.

Fiedler PC, Talley LD. 2006. Hydrography of the eastern tropical Pacific: A review. Prog. Oceanogr. 69: 143-180.

Gattuso JP, Frankignoulle M, Bourge I, Romaine S, Buddemeier RW. 1998. Effect of calcium carbonate saturation of seawater on coral calcification. Global Planet. Change 18: 37-46.

Glynn PW. 1977. Coral growth in upwelling and non-upwelling areas off the Pacific coast of Panama. J. Mar. Res. 35: 567-585.

Glynn PW, Ault JS. 2000. A biogeographic analysis and review of the far eastern Pacific coral reef region. Coral Reefs 19: 1-23.

Glynn PW, Leyte-Morales GE. 1997. Coral reefs of Huatulco, west Mexico: Reef development in upwelling Gulf of Tehuantepec. Rev. Biol. Trop. 45: 1033-1047.

Glynn PW, Wellington GM. 1983. Corals and Coral Reefs of the Galapagos Islands. University of California Press, Berkeley, $330 \mathrm{pp}$.

Guzmán HM, Cortés J. 1989. Growth rates of eight species of Scleractinian corals in the eastern Pacific (Costa Rica). Bull. Mar. Sci. 44: 1186-1194.

Halfar J, Godinez-Orta L, Riegl B, Valdez-Holguín JE, Borges JM. 2005. Living on the edge: High-latitude Porites carbonate production under temperate eutrophic conditions. Coral Reefs 24: 582-592.

Highsmith RC. 1979. Coral growth rates and environmental control of density banding. J. Exp. Mar. Biol. Ecol. 37: 105-125.
Hughes T. 1987. Skeletal density and growth form of coral. Mar. Ecol. Prog. Ser. 35: 259-66.

[IPCC] Intergovernmental Panel on Climate Change. 2007. Climate Change 2007: The Physical Science Basis. Contribution of Working Group I to the Fourth Assessment Report of the Intergovernmental Panel on Climate Change. Solomon S, Qin D, Manning M, Chen Z, Marquis M, Averyt KB, Tignor M, Miller HL (eds.). Cambridge Univ. Press, 396 pp.

Jiménez C, Cortés J. 2003. Growth of seven species of scleractinian corals in an upwelling environment of the eastern Pacific (Golfo de Papagayo, Costa Rica). Bull. Mar. Sci. 72: 187-198.

Jones AM, Berkelmans R, Van Oppen, MJ, Mieog JC, Sinclair W. 2008. A community change in the algal endosymbionts of a scleractinian coral following a natural bleaching event: Field evidence of acclimatization. Proc. R. Soc. Lond. (Biol. Sci.) 275: 1359-1365.

Kleypas JA, Langdon C. 2006. Coral reefs and changing seawater carbonate chemistry. Coral Reefs and Climate Change: Science and Management, Coastal and Estuarine Studies 61, American Geophysical Union, pp. 73-110.

Kleypas JA, McManus JW, Meñez LA. 1999. Environmental limits to coral reef development: Where do we draw the line? Am. Zool. 39: 146-159.

Knutson DW, Buddemeier RW, Smith SV. 1972. Coral chronometers: Seasonal growth bands in reef corals. Science 177: 270-272. http://dx.doi.org/10.1126/science.177.4045.270

LaJeunesse TC, Smith R, Walther M, Pinzón J, Pettay DT, McGinley M, Aschaffenburg M, Medina-Rosas P, CupulMagaña AL, López-Pérez A, Reyes-Bonilla H, Warner ME. 2010. Host-symbiont recombination versus natural selection in the response of coral-dinoflagellate symbioses to environmental disturbance. Proc. R. Soc. Lond. (Biol. Sci.) 277(1696): 2925-2934.

http://dx.doi.org/10.1098/rspb.2010.0385

Langdon C, Takahashi T, Sweeney C, Chipman D, Goddard J, Marubini F, Aceves H, Barnett H, Atkinson MJ. 2000. Effect of calcium carbonate saturation state on the calcification rate of an experimental coral reef. Global Biogeochem. Cycles 14: 639-654. http://dx.doi.org/10.1029/1999GB001195

López-Pérez A, Guendulain-García S, Granja-Fernández R, Hernández-Urraca V, Galván-Rowland L, Zepeta-Vilchis R, López-López D. 2016. Reef community changes associated with the 2009-2010 El Niño in the southern Mexican Pacific 1. Pac. Sci. 70: 175-190.

López-Pérez RA, Calderón-Aguilera LE, Reyes-Bonilla H, Carriquiry JD, Medina-Rosas P, Cupul-Magaña AL, Luna-Salguero BM. 2012. Coral communities and reefs from Guerrero, southern Mexican Pacific. Mar. Ecol. 33: 407-416.

López-Pérez RA, Hernández-Ballesteros LM. 2004. Coral community structure and dynamics in the Huatulco area, western Mexico. Bull. Mar. Sci. 75: 453-472.

López-Pérez RA, Mora-Pérez MG, Leyte-Morales GE. 2007. Coral (Anthozoa: Scleractinia) recruitment at Bahías de Huatulco, western México: Implications for coral community structure and dynamics. Pac. Sci. 61(3): 355-369.

Lough JM, Barnes DJ. 1997. Several centuries of variation in skeletal extension, density and calcification in massive Porites colonies from the Great Barrier Reef: A proxy for seawater temperature and a background of variability against which to identify unnatural change. J. Exp. Mar. Biol. Ecol. 211: 29-67.

Lough JM, Barnes DJ. 2000. Environmental controls on growth of the massive coral Porites. J. Exp. Mar. Biol. Ecol. 245: 225-243. 
Lough JM, Barnes DJ, Devereux MJ, Tobin BJ, Tobin S. 1999. Variability in growth characteristics of massive Porites on the Great Barrier Reef. Tech. Rep. no. 28, CRC Reef Research Center, Townsville, $95 \mathrm{pp}$.

Loya Y. 1976. Effects of water turbidity and sedimentation on the community structure of Puerto Rican corals. Bull. Mar. Sci. 26: $450-466$

Manzello DP. 2010. Coral growth with thermal stress and ocean acidification: Lessons from the eastern tropical Pacific. Coral Reefs 29: 749-758.

Manzello DP, Kleypas JA, Budd DA, Eakin CM, Glynn PW, Langdon C. 2008. Poorly cemented coral reefs of the eastern tropical Pacific: Possible insights into reef development in a high-CO2 world. Proc. Natl. Acad. Sci. USA 105: 10450-10455.

Marubini F, Atkinson MJ. 1999. Effects of lowered pH and elevated nitrate on coral calcification. Mar. Ecol. Prog. Ser. 188: $117-121$

Marubini F, Barnett H, Langdon C, Atkinson MJ. 2001. Dependence of calcification on light and carbonate ion concentration for the hermatypic coral Porites compressa. Mar. Ecol. Prog. Ser. 220: $153-162$

Morales R, Vélez H, Mejía A, Ramírez I, Izurieta J, Saldaña P. 2008. Hidrodinámica de la Bahía de Zihuatanejo, México. XXIII Congreso Latinoamericano de Hidráulica, 2-6 September 2008, Cartagena de Indias, Colombia.

Muller-Parker G, McCloskey LR, Hoegh-Guldberg O, McAuley PJ. 1994. Effect of ammonium enrichment on animal and algal biomass of the coral Pocillopora damicornis. Pac. Sci. 48: 273-283.

Norzagaray-López CO, Ávila-López MC, Chapa-Balcorta C, Calderón-Aguilera LE, Hernández-Ayón M. 2013. Reducida producción de $\mathrm{CaCO}_{3}$ por Porites panamensis en tres comunidades arrecifales del Pacífico mexicano. In: Pellat FP, González JW, Bazan M, Saynes V (eds.), Estado Actual del Conocimiento del Ciclo del Carbono y sus Interacciones en México: Síntesis a 2013. Programa Mexicano del Carbono, México, pp. 437-441.

Norzagaray-López CO, Calderón-Aguilera LE, Hernández-Ayón JM, Reyes-Bonilla H, Carricart-Ganivet JP, Cabral-Tena RA, Balart EF. 2014. Low calcification rates and calcium carbonate production in Porites panamensis at its northernmost geographic distribution. Mar. Ecol. 36: 1244-1255.

Reyes-Bonilla H. 2003. Coral Reefs of the Pacific Coast of Mexico. Latin American Coral Reefs, 331 pp.

Reyes-Bonilla H, Calderón-Aguilera LE. 1994. Parámetros poblacionales de Porites panamensis (Anthozoa: Scleractinia), en el arrecife de Cabo Pulmo, México. Rev. Biol. Trop. 42: 121-128.

Reyes-Bonilla H, Calderón-Aguilera LE, Mozqueda-Torres MC, Carriquiry JD. 2014. Presupuesto de carbono en arrecifes coralinos de México. Interciencia 39: 645.

Reyes-Bonilla H, Carriquiry J, Leyte-Morales G, Cupul-Magaña A. 2002. Effects of the El Nino-Southern Oscillation and the antiEl Nino event (1997-1999) on coral reefs of the western coast of Mexico. Coral Reefs 21: 368-372.

Reyes-Bonilla H, Escobosa-González LE, Cupul-Magaña AL, Medina-Rosas P, Calderón-Aguilera LE. 2013. Estructura comunitaria de corales zooxantelados (Anthozoa: Scleractinia) en el arrecife coralino de Carrizales, Pacífico mexicano. Rev. Biol. Trop. 61: 583-594.

Reyes-Bonilla H, Leyte-Morales GE. 1998. Corals and coral reefs of the Puerto Angel region, west coast of Mexico. Rev. Biol. Trop. 46: 679-681.

Reyes-Bonilla H, López-Pérez RA. 2009. Corals and coral-reef communities in the Gulf of California. In: Johnson ME, Ledesma-Vásquez J (eds.), Atlas of Coastal Ecosystems in the Gulf of California. Past and Present. University of Arizona Press, pp. 45-57.

Stambler N, Popper N, Dubinsky Z, Stimson J. 1991. Effects of nutrient enrichment and water motion on the coral Pocillopora damicornis. Pac. Sci. 45(3): 299-307.

Tortolero-Langarica JA, Rodríguez-Troncoso AP, Carricart-Ganivet JP, Cupul-Magaña AL. 2016. Skeletal extension, density and calcification rates of massive free-living coral Porites lobata Dana, 1846. J. Exp. Mar. Biol. Ecol. 478: 68-76.

Veron JEN. 1995. Corals in Space and Time: The Biogeography and Evolution of the Scleractinia. Cornell Univ. Press, Sydney, $321 \mathrm{pp}$.

Walther-Mendoza M, Reyes-Bonilla H, LaJeunesse TC, LópezPérez A. 2016. Distribución y diversidad de dinoflagelados simbióticos en corales pétreos de la costa de Oaxaca, Pacífico de México. Rev. Mex. Biodivers. 87: 417-426.

Wells JW. 1963. Coral growth and geochronometry. Nature 197: 948-950. http://dx.doi.org/10.1038/197948a0

Wellington GM, Glynn PW. 1983. Environmental influences on skeletal banding in eastern Pacific (Panama) corals. Coral Reefs 1: 215-222.

Yentsch CS, Yentsch CM, Cullen JJ, Lapointe B, Phinney DA. 2002. Sunlight and water transparency: Cornerstones in coral research. J. Exp. Mar. Biol. Ecol. 268: 171-183.

Zar JH. 2010. Biostatistical Analysis. Prentice-Hall, New Jersey, $944 \mathrm{pp}$. 